\title{
Experimental study and comparison of different fully transparent laminated glass beam designs
}

\author{
Xavier Centelles · J. Ramon Castro • F. Pelayo • \\ Manuel Aenlle-López • Luisa F. Cabeza $(1)$
}

Received: 6 June 2021 / Accepted: 17 August 2021 / Published online: 16 September 2021

(C) The Author(s) 2021

\begin{abstract}
Laminated glass beams without metallic or polymeric reinforcements generally lack post-breakage strength and ductility. This paper aims to perform a comparative study by testing five different fully transparent laminated glass beam designs in order to see how parameters such as the number and thickness of glass sheets $(3 \times 10 \mathrm{~mm}$ or $5 \times 6 \mathrm{~mm})$, the interlayer material (PVB Clear or SentryGlas), and the thermal treatment of glass (annealed or heat-strengthened) affect the pre-breakage performance and post-breakage safety. A buckling analysis is also performed using a numerical model with ABAQUS CAE. The study includes a comparison between the results of different experimental mechanical tests on laminated glass beams, including the tests presented in this paper, as well as other tests found in the literature. All designs presented a linear elastic behaviour until initial breakage. The interlayer material mainly affected the crack shape of laminated glass beams. Beams with five sheets of annealed glass had a more progressive breakage, and therefore a safer behaviour, than beams with three sheets of annealed or heat-strengthened glass.
\end{abstract}

X. Centelles· J. R. Castro · L. F. Cabeza ( $\square)$

GREiA Research Group, University of Lleida, Pere de

Cabrera s/n, 25001 Lleida, Spain

e-mail: luisaf.cabeza@udl.cat

F. Pelayo· M. Aenlle-López

Department of Construction and Manufacturing Engineering, University of Oviedo, Campus de Gijón, Zona Oeste, Edificio 7, 33203 Gijón, Spain
Keywords Laminated glass beams · Four-point bending test $\cdot$ Interlayer material $\cdot$ Lateral-torsional buckling · Finite element (FE) numerical modelling

\section{Introduction}

Modern architecture aims to create buildings with a higher level of transparency, in order to increase the natural sunlight indoors and bring the occupants closer to its surroundings. To do so, the use of glass, which originally was limited to windows, later expanded to transparent facades and roofs. In more recent singular buildings, even the structural elements (beams and columns) that support the glazing elements are made of glass.

The main safety problem when using glass for structural applications is its lack of load capacity and ductility after breakage. Its brittle behaviour is a great limitation in its use and in the sizing of the elements. In addition to that, when a glass sheet breaks, the glass fragments can be projected causing injuries to the occupants Kozłowski (2019). This same problem was also experienced in car windshields, because glass is prone to breakage due to hard body impacts Chen et al. (2016), such as rocks, or soft body impacts (Liu et al. 2016; Wang and Yue 2010), such as pedestrians or animals, which could cause the loss of integrity of the glass windshield and severe injuries to the passengers or the pedestrians. That is why laminated glass was invented and initially used in car windshields in order to pre- 
vent glass shards from scattering in case of accidental breakage Xu et al. (2011).

Laminated glass is a composite laminate that combines two or more sheets of glass with a polymeric interlayer to bond the glass layers together. The chemical bond between glass and interlayer can be obtained by creating the vacuum between layers and applying a certain temperature cycle in an autoclave Martín et al. (2020). Some other materials, such as UV-curing adhesives, do not require an autoclave to create the bond between glass and interlayer. Polyvinyl butyral (PVB) was the first material used as interlayer material, and it is still the most commonly used in windshield glazing Chen et al. (2017).

Laminated glass was later used in architecture, mainly to preserve the element integrity and to protect against the projection of broken glass fragments Galuppi and Royer-Carfagni (2018). Stiffer interlayers such as SentryGlas were developed for special applications such as hurricane and burglary resistant glazing Louter et al. (2012). Due to its good behaviour in challenging situations from a structural point of view, stiffer interlayers were later also used in structural elements such as laminated glass beams, floors, columns, and staircases Valarinho et al. (2016).

SentryGlas is an ionomer that presents a higher strength and stiffness than standard PVB Centelles et al. (2020). It has a higher glass transition temperature than standard PVB and most of the commercial interlayer materials Martín et al. (2020). It presents a good adhesion with both glass and steel (Santarsiero et al. 2017, 2016), and that makes it an adequate candidate for embedded joints in laminated glass elements (Santarsiero et al. 2018; Bedon and Santarsiero 2018) and laminated glass beams with metallic reinforcements (Louter et al. 2012; Bedon and Louter 2017).

There are other polymers used as interlayers for laminated glass, with certain properties that make them adequate for some specific applications. Ethylenevinyl acetate (EVA), is a copolymer of ethylene and vinyl acetate. It is commonly used in protective laminated glass for PV modules (Jentsch et al. 2015; Lyu et al.2018), because it has an excellent optical transmission and a good resistance to UV radiation Bridgestone (2016). Thermoplastic polyurethane (TPU) is another copolymer that combines soft segments, which provide ductility, and hard segments which provide stiffness and tensile strength. TPU has a high adhesion not only with glass, but also with other transparent stiff polymers such as poly(methyl methacrylate) (PMMA) or polycarbonate (PC) (Rühl et al. 2020; Rivers and Cronin 2019), and for that reason it is commonly used in bulletproof glass or other composite laminates that combine glass with PMMA or PC Weller et al. (2009).

Laminated glass structural elements can be loaded with out-of-plane loads, as for example in roofs and floors or in-plane loads, as for example in beams and columns. This paper focuses on laminated glass beams under in-plane loading. Figure 1 shows the experimental setup of the bending test presented in this paper.

In laminated glass elements under out-of-plane loading, the interlayer material experiences an angular distortion caused by the relative displacement between the bonded glass surfaces. As a consequence, the interlayer transfers shear stresses proportional to its shear stiffness and angular distortion. The stiffer the interlayer, the higher the bending stiffness and flexural load of laminated glass under out-of-plane loading (Galuppi and Royer-Carfagni 2012; Calderone et al. 2009; Galuppi et al. 2013; Pelayo et al. 2017).

The interlayer is thinner, softer and weaker than the glass sheets. For that reason, the contribution of the interlayer in the pre-breakage flexural response of laminated glass beams is negligible (Galuppi and RoyerCarfagni 2018; Belis et al. 2009), because there is no relative displacement between confronted glass surfaces, and therefore no shearing stresses on the interlayer López-Aenlle et al. (2019). By contrast, the shear modulus of the interlayer affects the lateral stability of laminated glass beams when subjected to in-plane bending, undergoing lateral-torsional buckling (Pelayo et al. 2017; Bedon et al. 2014). Lateral-torsional buckling is strongly affected not only by the in-plane inertia, but also by the out-of-plane inertia and by the torsional stiffness, which are in turn affected by the degree of coupling offered by the interlayer (Belis et al. 2013; Machado-e-Costa et al. 2016; Galuppi and Royer-Carfagni 2020).

The shear stiffness of the interlayer also affects the failure mechanism: laminated glass beams with softer interlayers experience a higher local delamination in the cracked region Belis et al. (2009). In partially broken laminated glass beams, the interaction between broken glass sheets and interlayers provides a beneficial additional stiffness to the unbroken glass sheets (Biolzi et al. 2018; Bonati et al. 2019). That stiffening effect is more representative with stiffer interlayers, since these 
Fig. 1 Bending test on a laminated glass beam

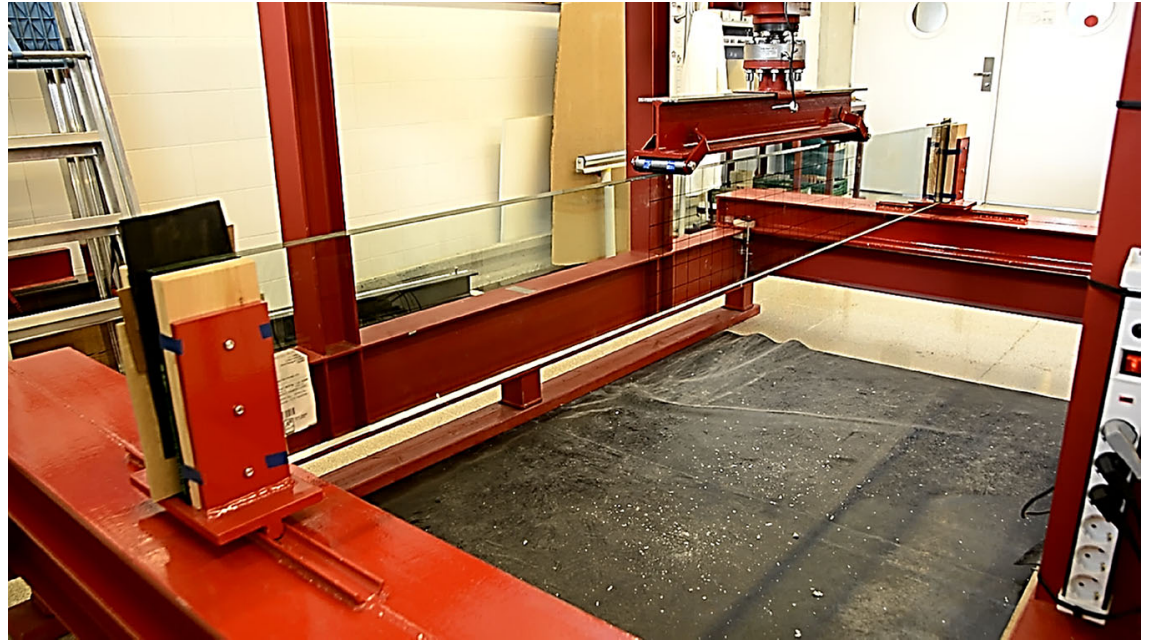

have a higher capacity to transfer shear stresses with smaller angular distortions Serafinavičius et al. (2013).

Annealed glass has a linear elastic behaviour: annealed float glass has a modulus of elasticity of 70 $\mathrm{GPa}$, and a bending strength of 30-80 MPa Feldmann et al. (2014). The bending strength of glass has a high variability because it is a brittle material, and its breakage is mainly due to the presence of small surface flaws randomly scattered To et al. (2008), which may appear during the manufacturing, transportation, assembly or service life of glass elements Lindqvist and Louter (2014). When a critical stress or strain is surpassed, the surface flaws grow uncontrollably Griffith (1921). The load duration may also affect the strength of glass CENTC250WG3 (2013), because the exposure to weathering factors, especially temperature and humidity, combined with stress, can cause stress corrosion and lead to subcritical crack growth Ronchetti et al. (2013). Glass can be subjected to thermal treatments in order to increase its bending strength. Depending on the degree of induced surface pre-compression, thermally-treated glass can be classified as heat-strengthened glass or tempered glass. The thermal treatment also affects the breakage mode of glass: the higher the surface precompression, the higher the elastic strain energy release when breakage starts, and therefore the higher the crack density (Griffith 1921; Bos 2009).

Another glass surface strengthening process is known as chemical strengthening Karlsson et al. (2010). The most common chemical strengthening process is the one conducted at low temperature, based on replacing some of the surface sodium atoms of glass by larger atoms, generally potassium, which put the glass surface into compression. The compression layer is much thinner than the one in heat strengthened glass.

The main issue of structural elements made of glass is that it is a brittle material, and therefore, since it is unable to redistribute peak stresses or stop crack propagation, it is prone to failure due to accidental or unexpected causes Bos (2009). Besides, when designing a structural glass element, one must assume that it may break, but must do so in a safe way, so that the initial breakage does not lead to total structural collapse. For that reason, post-breakage strength and ductility are seen as two key performance indicators.

Glass may also break due to abrupt temperature variations, which could lead to high thermal gradients within a single element, and therefore uneven thermal expansion Bokel et al. (2003). High temperatures may also decrease the strength and shear stiffness of polymeric interlayers (Pelayo et al. 2017; Andreozzi et al. 2014), or even cause adhesion loss between glass and interlayer. Some authors have evaluated the fire resistance of structural elements made of glass Louter and Nussbaumer (2016), or glass combined with other materials [48], as well as the application of transparent protective coatings in order to delay the impact caused by fire on laminated glass Veer et al. (2013).

Many authors proposed different solutions for a safe design of laminated glass elements. Martens et al. Martens et al. (2016) collected information about laminated glass beams with steel reinforcements or pre-stressing strands. Both of these solutions were initially implemented in concrete construction in order 
to increase the tensile strength, transforming a brittle material (concrete) in a more ductile material (reinforced concrete), and therefore achieving the required safety in reinforced concrete beams under bending loads. The steel reinforcements have the capacity to deform plastically after glass fracture, providing a higher post-breakage strength and ductility. It is also possible to increase the post-breakage safety by combining glass with another construction material such as timber, steel, or reinforced concrete Martens et al. (2015), although that additional material reduces the sought transparency of the structural element. Other authors proposed using statically indeterminate designs, either with redundant boundary conditions Martens et al. (2016) or sacrificial glass sheets Biolzi et al. (2010). All these designs aim to provide a safety margin between the initial fracture, which serves as a warning of structural overload or accidental breakage, and the final collapse, when the structural element loses all its load-bearing capacity.

In this paper, a four-point bending test until total collapse is performed on five different laminated glass beam designs. All designs are fully transparent and lack any type of additional reinforcement. The five designs have in common the external dimensions, but have differences in other parameters, such as the interlayer material, the number and thickness of the glass sheets, and the thermal treatment of the glass. The main goal of this paper is to see how these factors affect the performance and safety of laminated glass beams. The performance and safety are measured based on four indicators, described in the methodology part of this paper: bending stiffness, pre-breakage strength, redundancy, and breakage mode.

Although lateral displacement and rotation is restricted at the supports at both ends of the beam, lateral torsional buckling is something that may occur and must be studied. For this reason, a buckling analysis is performed using ABAQUS CAE (H2020). The numerical simulation results are then compared with the experimental values in order to evaluate if lateral torsional buckling may have contributed to the collapse of any of the tested laminated glass beams.

\section{Materials}

Five different beam designs were tested and compared. All designs were fully transparent, which means that they had no opaque reinforcements, and had the same external dimensions: 30 × 300 × $3100 \mathrm{~mm}$. The different cross section designs and materials are presented in Fig. 2. There were three replicates of each beam design.

The edge finishing applied in all glass layers was bright polishing. Bright polishing was performed before lamination and before thermal strengthening. Polishing after lamination can be done in annealed glass layers, but the most common procedure is to do it before. Polishing after thermal strengthening would lead to glass fracture. The thermal treatment was carried out in a Tamglass tempering oven, following a standard procedure, with temperatures up to $700^{\circ} \mathrm{C}$, and a slower cooling rate than for tempered glass.

The glass manufacturer that supplied the laminated glass beams was CRISTEC Glass. That company uses smaller dimensional tolerances for glass misalignment than the ones proposed by design guides for structural glass CEN/TC 250 (2019).

The interlayer thickness was the same in all cases: $1.52 \mathrm{~mm}$. The two different interlayer materials used were PVB Clear and SentryGlas. PVB Clear is a special type of polyvinyl butyral, with an enhanced transparency but the same mechanical properties as the standard PVB commonly used in glazing. SentryGlas is an ionomer commonly used in glass elements with more demanding structural requirements. It presents a good adhesion to both glass and metals, and a higher stiffness and glass transition temperature than standard PVB Martín et al. (2020). Both interlayer materials were supplied by Kuraray Europe GmbH. The reason why these two interlayer materials were chosen is because PVB is the most commonly used interlayer for many applications, including but not limited to glazing for buildings Martín et al. (2020) and automotive windshields (Chen et al. 2017; Gao et al. 2019), and SentryGlas is a widely used alternative for structural applications (Bedon and Louter 2017; Belis et al. 2009; Martens et al. 2016, ?).

The beam design 1 has three annealed glass sheets, of thickness $10 \mathrm{~mm}$ each, and PVB Clear interlayer. The beam design 2 also has three annealed glass sheets, but SentryGlas interlayer. Designs 3 and 4 are the same as designs 1 and 2 respectively, but with five glass sheets of thickness $6 \mathrm{~mm}$ each. Design 5 has three sheets of heat-strengthened glass and SentryGlas interlayer. The characteristics of each of the five designs are listed in Table 1.

From these five different designs it will be possible to study the three different studied parameters sepa- 


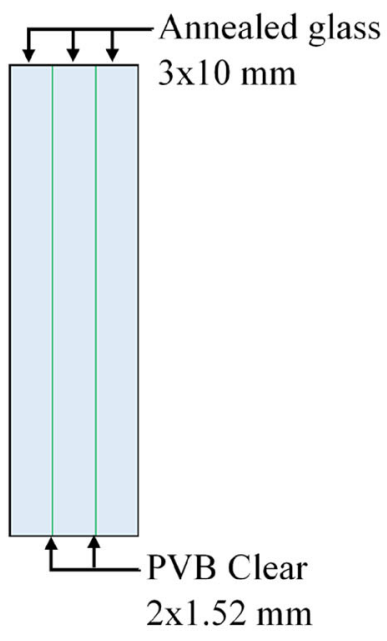

(a) Design 1

(d) Design 4

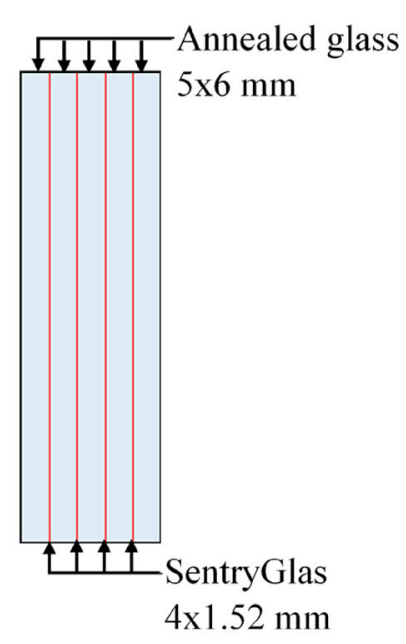

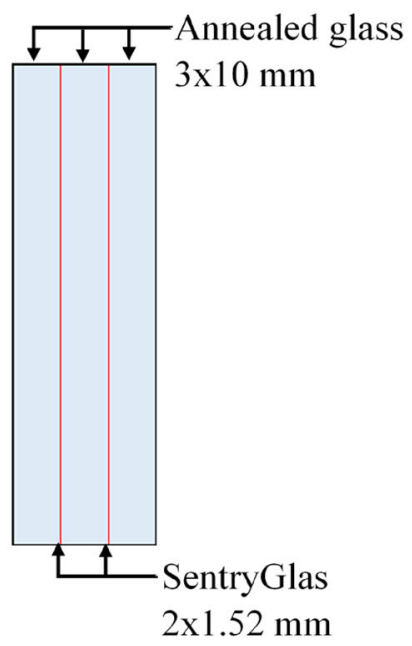

(b) Design 2

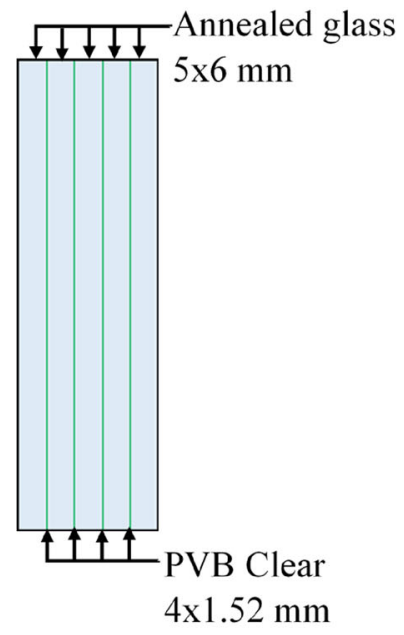

(c) Design 3

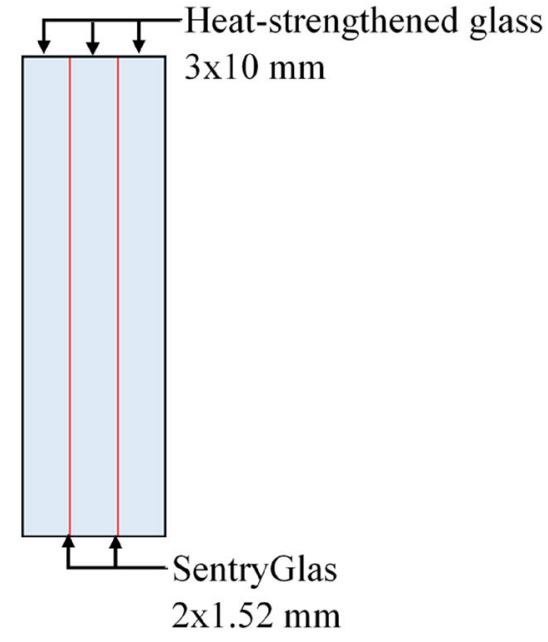

(e) Design 5

Fig. 2 Cross section of the five laminated glass beams designed and tested

rately: interlayer material, number of sheets, and type of glass. The contribution of the interlayer material can be studied by comparing Designs 1 with 2, and 3 with 4. The effect of the number of glass sheets can be evaluated by comparing Design 1 with 3 , and 2 with 4 . Finally, the influence of the type of glass can be seen by comparing Design 2 with 5 .

All designs present a similar economic cost in terms of raw materials, except that SentryGlas is more expensive than PVB Clear, and heat strengthened glass requires an additional -yet very common- thermal pro- cess. The edge finish is the same for both annealed and heat-strengthened glass sheets. Specimens were laminated by CRISTEC Glass S.L. in Lleida (Spain).

\section{Methodology}

\subsection{Experimental set-up}

The laminated glass beams were subjected to the fourpoint bending test presented in Fig. 3. The test set-up was similar to the one carried out by Speranzini and 
Table 1 Main differences between the five tested beam designs

\begin{tabular}{llll}
\hline $\begin{array}{l}\text { Design } \\
\text { number }\end{array}$ & $\begin{array}{l}\text { Interlayer } \\
\text { material }\end{array}$ & $\begin{array}{l}\text { Number of } \\
\text { glass sheets }\end{array}$ & Type of glass \\
\hline 1 & PVB Clear & $3 \times 10 \mathrm{~mm}$ & Annealed \\
2 & SentryGlas & $3 \times 10 \mathrm{~mm}$ & Annealed \\
3 & PVB Clear & $5 \times 6 \mathrm{~mm}$ & Annealed \\
4 & SentryGlas & $5 \times 6 \mathrm{~mm}$ & Annealed \\
5 & SentryGlas & $3 \times 10 \mathrm{~mm}$ & Heat-strengthened \\
\hline
\end{tabular}

Agnetti (2015). The distance between supports was $3000 \mathrm{~mm}$, and the distance between the load application points was $950 \mathrm{~mm}$. There were lateral restraints at both ends to prevent out-of-plane buckling of the beams. The two top supports had a downwards displacement rate of $1 \mathrm{~mm} / \mathrm{min}$, controlled by a draw wire sensor with a range of $1250 \mathrm{~mm}$ by Waycon. The chosen displacement rate was the slowest that the system allowed, and it is within the typical range for this type of tests, which can go from $0.1 \mathrm{~mm} / \mathrm{min}$ Santarsiero et al. (2017) to $2 \mathrm{~mm} / \mathrm{min}$ Louter et al. (2012). The load application points were connected to a $100 \mathrm{kN}$ load cell by Transdutec. The data was transferred and stored using a Hoywin 32 PMS software by Proetisa at a frequency of $100 \mathrm{~Hz}$.

The laminated glass beams were supported at both ends on metallic profiles which allowed free rotation on the horizontal axis perpendicular to the beam. In addition to that, there were wooden supports at both sides of the beams to restrict the rotation on the longitudinal axis and the vertical axis. On top of the beam, the load was applied on two points by transferring the load from a metallic profile to two metallic rollers, and then to the beams. Rubber sheets $2 \mathrm{~mm}$ thick were placed between the laminated glass beams and the metallic or wooden elements in order to prevent direct contact between glass and other stiff materials, which could lead to premature, undesired breakage Centelles et al. (2019). These rubber sheets may have a small effect on the mechanic response measured during the test. However, all specimens have the same rubber sheets, and therefore it does not interfere in the comparative study between designs.

The maximum shearing loads, bending moments, and deflections of a four-point bending test are the ones presented in Fig. 4. The main advantages of performing a four-point bending test instead of a three-point bend- ing test are that there are no shearing loads in the central region, where the bending moment is highest and constant, and that the maximum bending is distributed in a region instead of a single point.

\subsection{Key performance indicators}

Different key performance indicators were chosen in order to study and compare the performance and safety of the five different beam designs. In terms of prebreakage performance, the chosen parameters were the bending stiffness and the maximum pre-breakage bending moment (i.e. before the initial cracking of the glass sheets). The bending stiffness is defined as the Young modulus (E) multiplied by the moment of inertia (I). It can be obtained from the beam deflection equation (Eq. 1), by isolating the term $E \cdot I$ (Eq. 2), where $\delta_{\mathrm{B}}$ is the maximum pre-breakage displacement measured by the draw wire displacement sensor, and $2 \cdot P$ the load measured by the load cell. The maximum bending moment is the one at the central region between the two load application points, as indicated in Fig. 4.

$$
\begin{aligned}
\delta_{B} & =\frac{\mathrm{P} \cdot \mathrm{a}^{2}}{6} \cdot \mathrm{E} \cdot \mathrm{I}(3 \cdot \mathrm{L}-4 \cdot \mathrm{a}) \\
E \cdot I & =\frac{\mathrm{P} \cdot \mathrm{a}^{2}}{6 \cdot \delta_{B}}(3 \cdot \mathrm{L}-4 \cdot \mathrm{a})
\end{aligned}
$$

The chosen post-breakage parameters were redundancy and breakage mode. According to Bos Bos (2009), redundancy is the most important safety property for laminated glass structural elements: it is the difference between the maximum load and the maximum pre-breakage load. The higher the redundancy, the bigger the safety margin in case of accidental breakage or overloading. If the maximum load is reached in the pre-breakage stage, then the redundancy value is zero. In order to study the breakage mode, a square mesh of $5 \times 5 \mathrm{~cm}$ was drawn on the central one-third of all the specimens before being tested (Fig. 5). That allowed to determine more accurately the crack size and crack density.

\section{Results}

The load-displacement diagrams are presented in Fig. 6. Each diagram has three curves, which correspond to the 
Fig. 3 Four-point bending test setup

Fig. 4 Shearing loads, bending moments and maximum deflection on a four-point bending test

Fig. 5 Square mesh in the central region of the laminated glass beams, where breakage is expected to occur
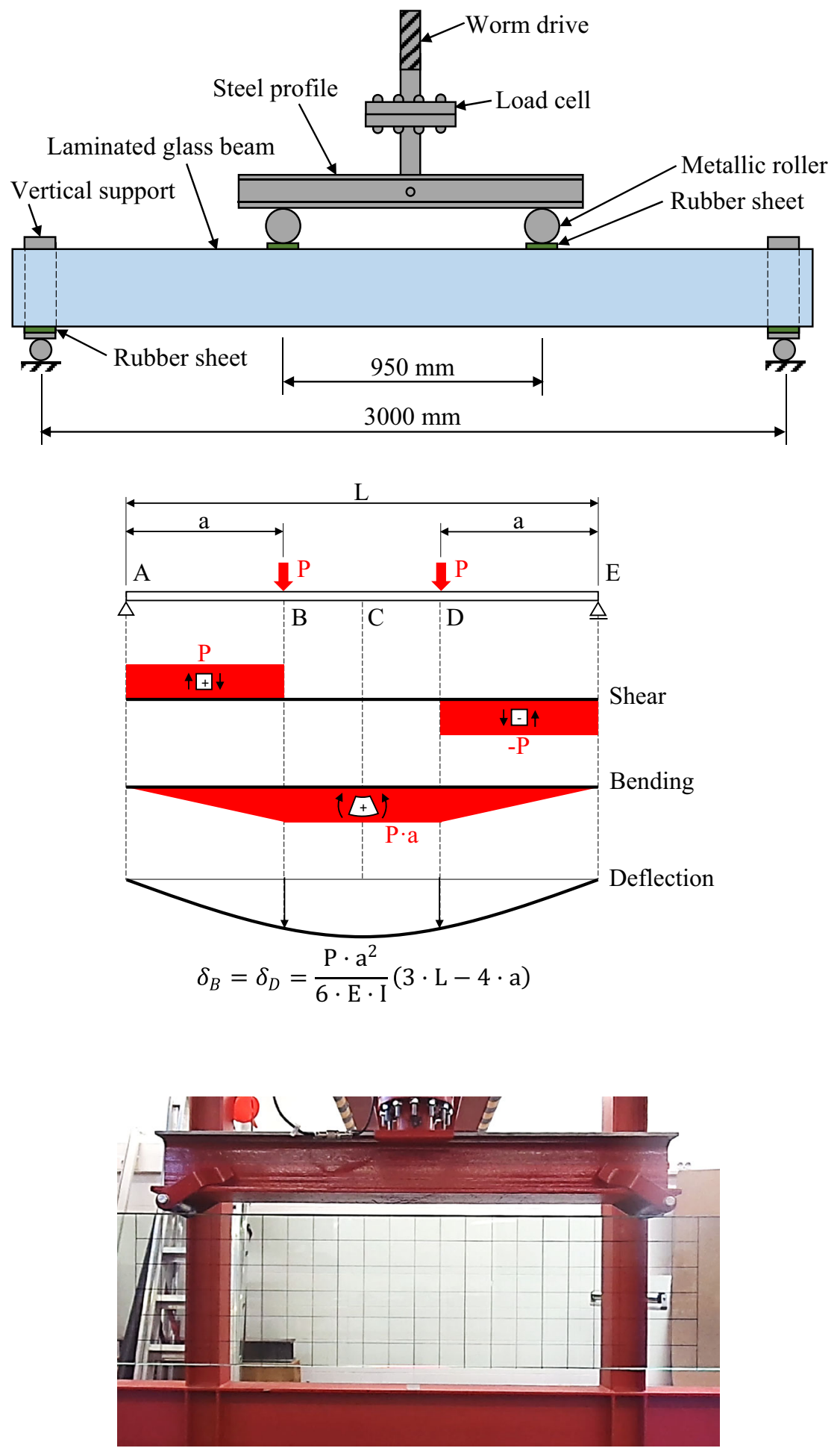


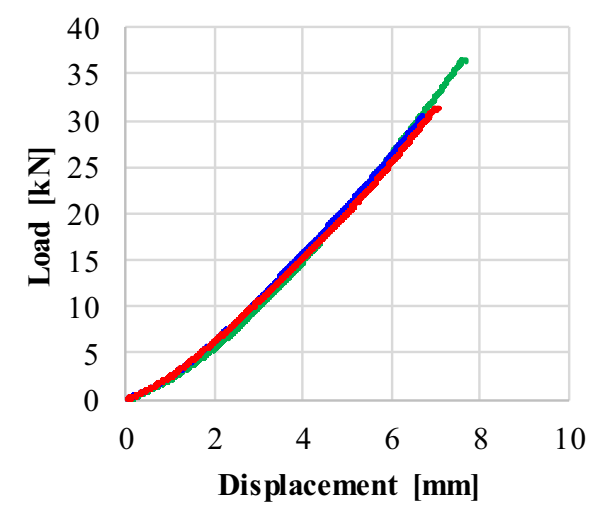

(a) Design 1

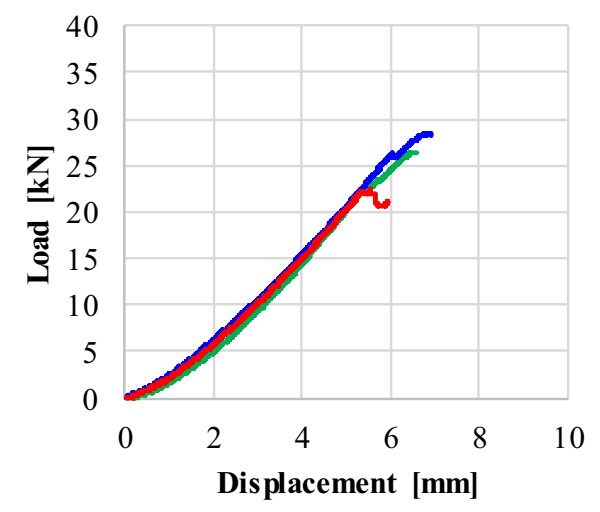

(c) Design 3

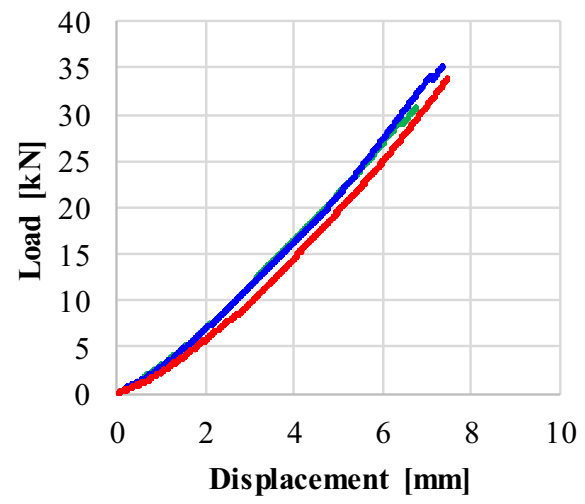

(b) Design 2

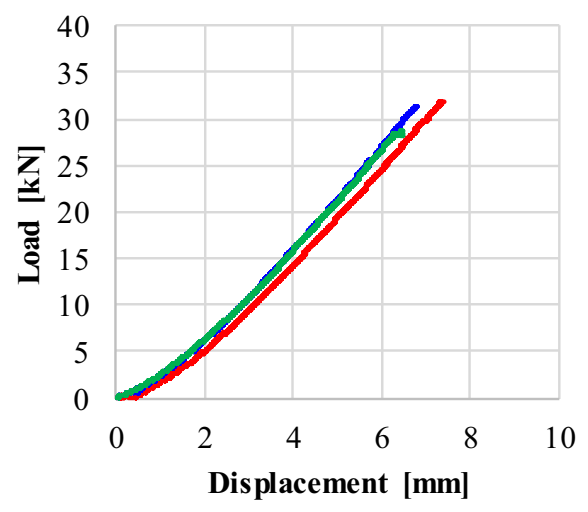

(d) Design 4

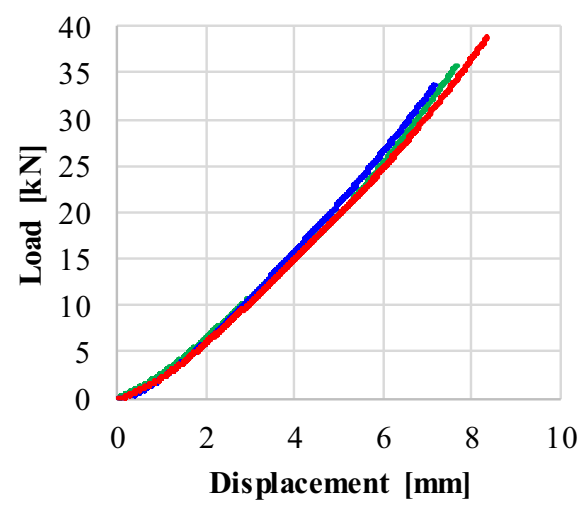

(e) Design 5

Fig. 6 Load-displacement diagram of each of the five beam designs. Each colour corresponds to one of the three replicates for each design 
$3 \mathrm{E}+12$

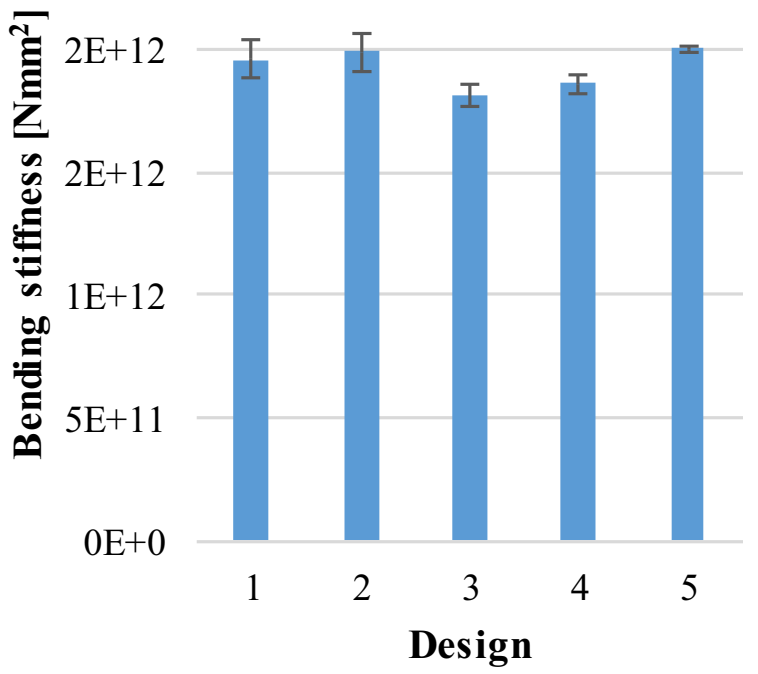

Fig. 7 Bending stiffness with a 95\% confidence interval

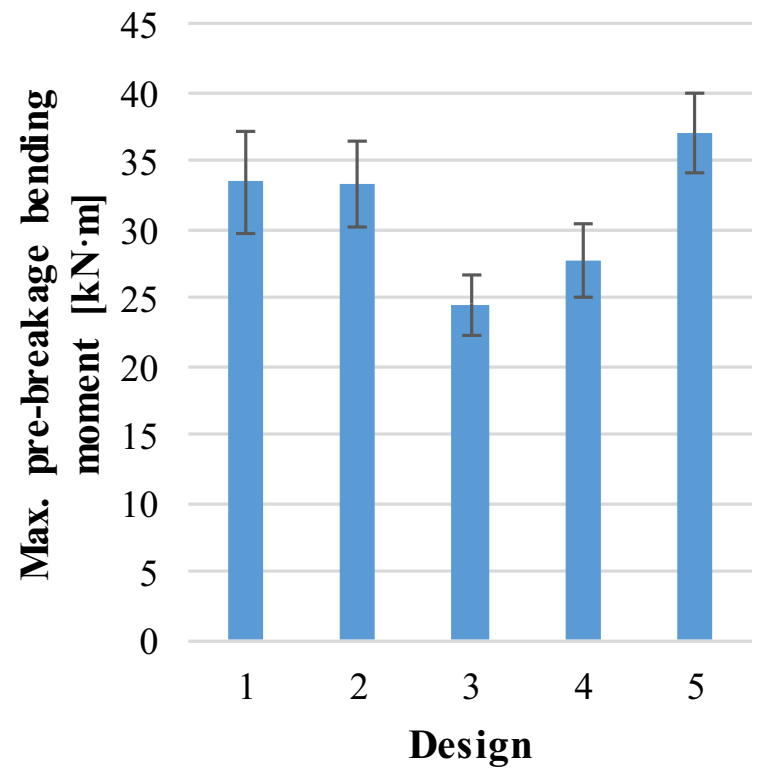

Fig. 8 Maximum pre-breakage bending moment with a 95\% confidence interval

three replicates of each design. The load was measured by the load cell, and the displacement by a displacement sensor, both placed on top of the upper supports. The change of tendency of the curves from the preto the post-breakage stages is almost unperceivable in most cases.
7000

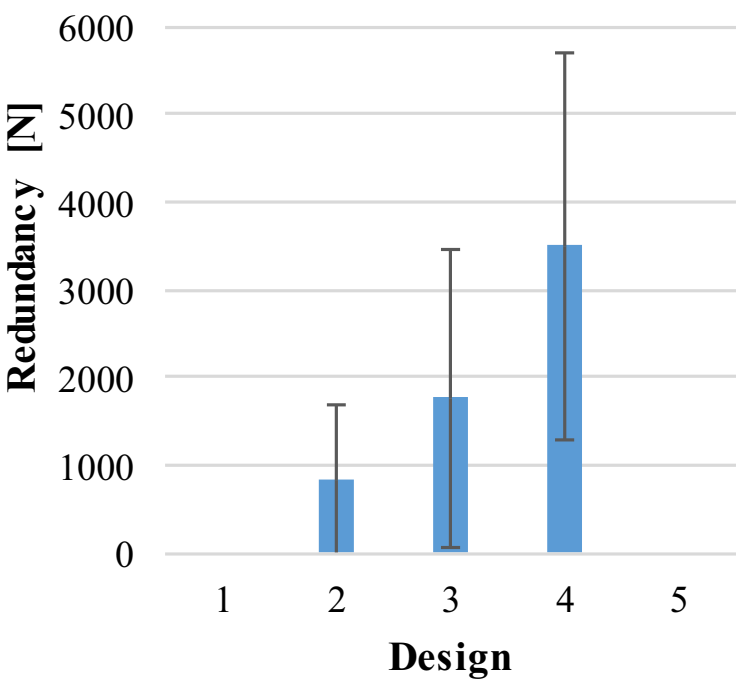

Fig. 9 Redundancy values with a 95\% confidence interval

The more relevant pre-breakage performance indicators, bending stiffness and maximum pre-breakage bending moment, are presented in Figs. 7 and 8, respectively. The column diagrams include $95 \%$ confidence intervals.

The redundancy of each design is also presented in a column diagram in Fig. 9. Redundancy was zero for all specimens of designs 1 and 5. In addition to that, the images of the initial cracking and final collapse of each laminated glass beam, grouped by design, are presented in Figs. 10, 11, 12, 13, 14. All numerical results are summarized in Table 2.

\section{Discussion}

5.1 Mechanical response of laminated glass beams

Figure 6 shows how all beam designs present a linear elastic behaviour until glass breakage. The specimens present only a slightly nonlinear behaviour at the beginning, but that may be due to the deflection of the 2 $\mathrm{mm}$ thick rubber sheets placed between the laminated glass beam and the metallic rollers on top, and between the laminated glass beam and the metallic supports at the bottom. Only after initial glass fracture some specimens present an irregular, nonlinear behaviour until total collapse. 


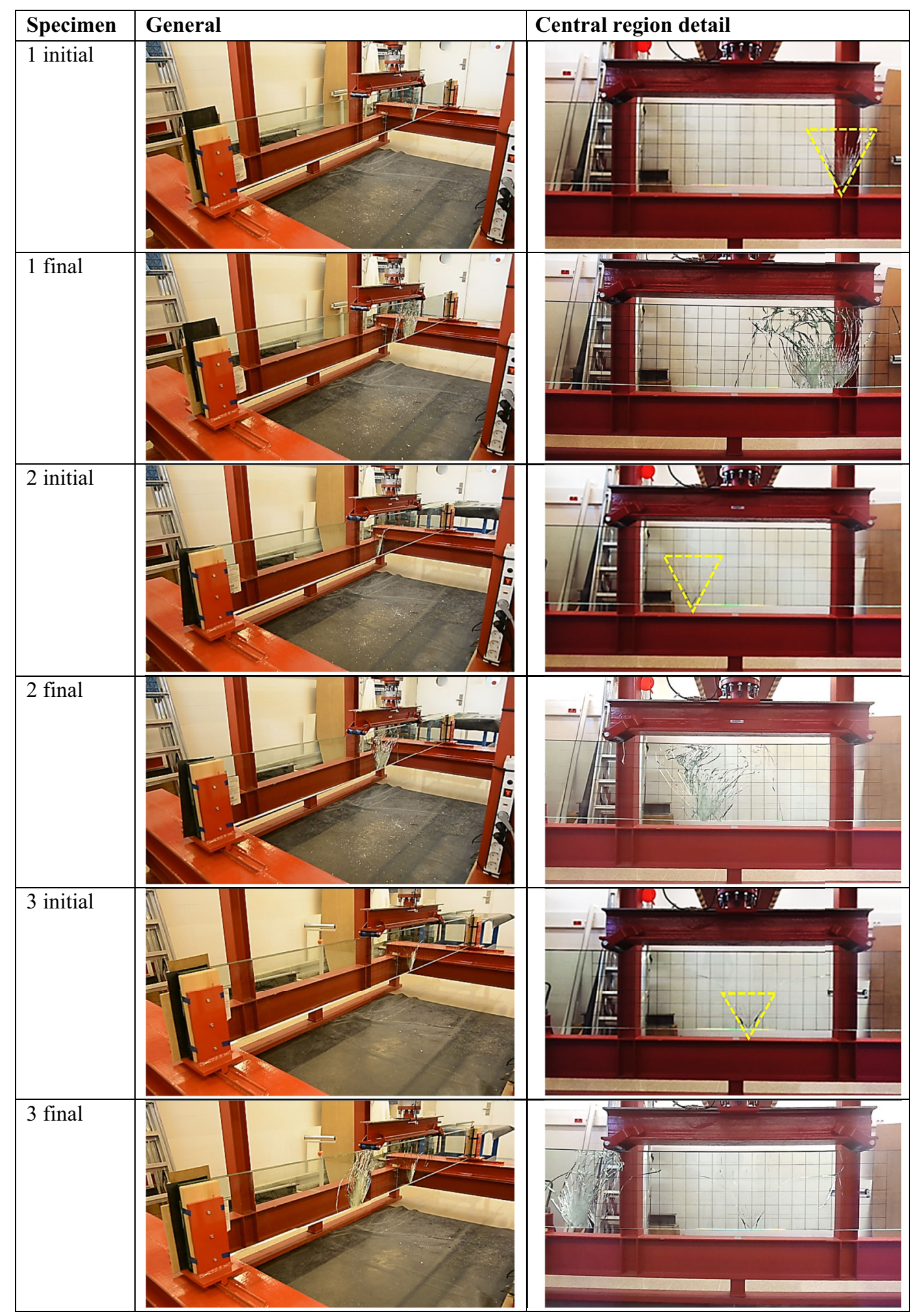

Fig. 10 Initial breakage and final collapse of specimens of the beam design 1 


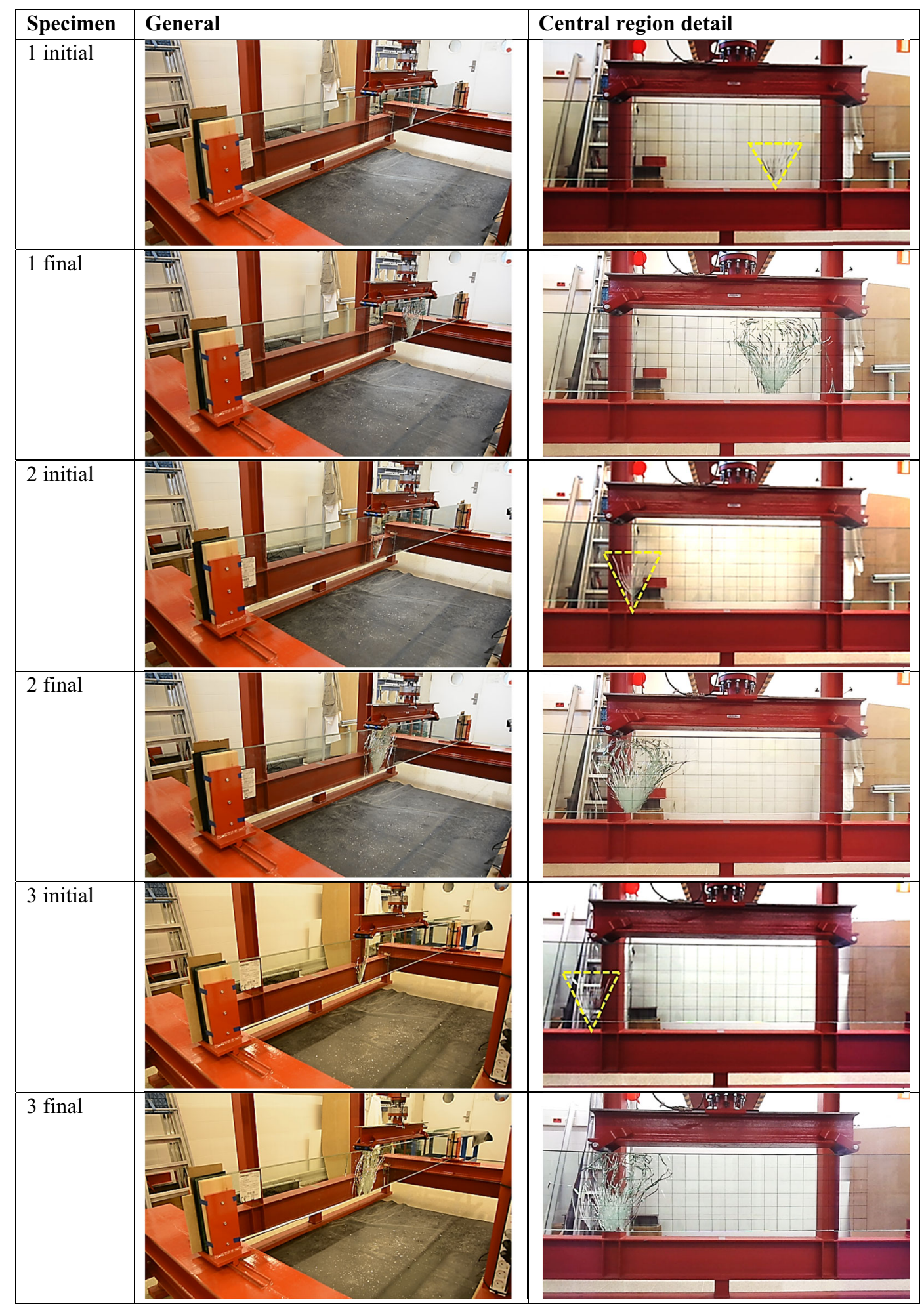

Fig. 11 Initial breakage and final collapse of specimens of the beam design 2 


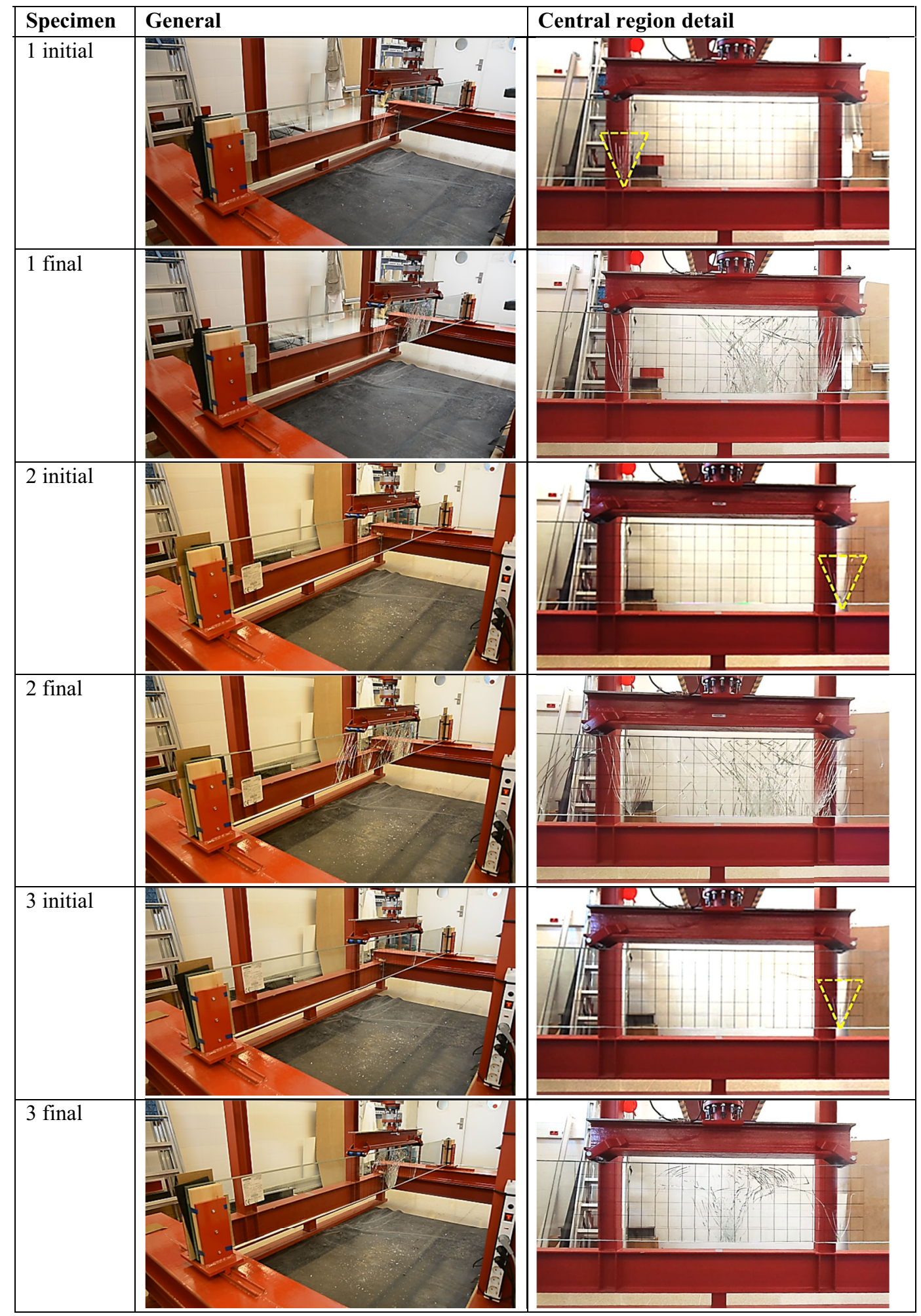

Fig. 12 Initial breakage and final collapse of specimens of the beam design 3 


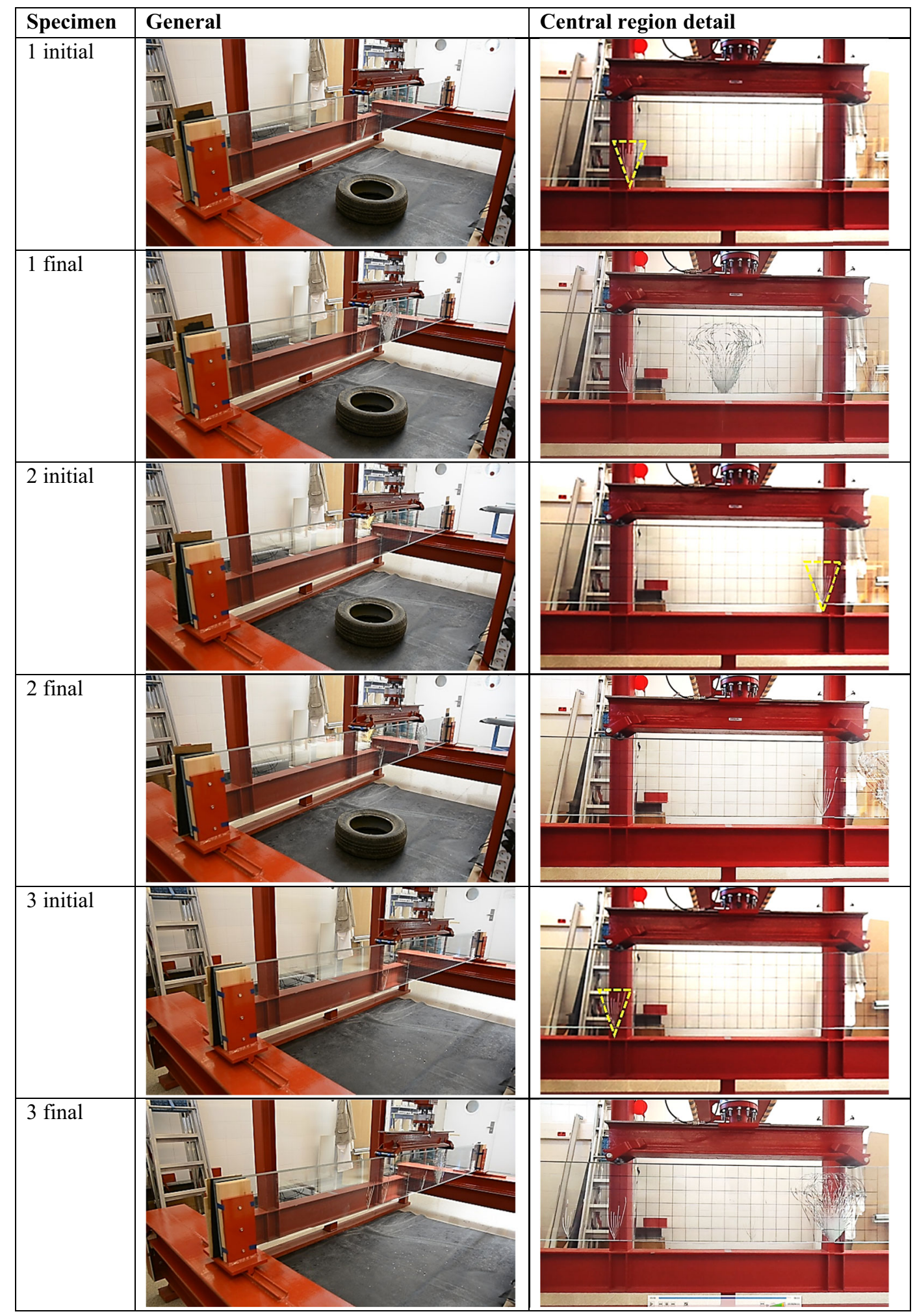

Fig. 13 Initial breakage and final collapse of specimens of the beam design 4 


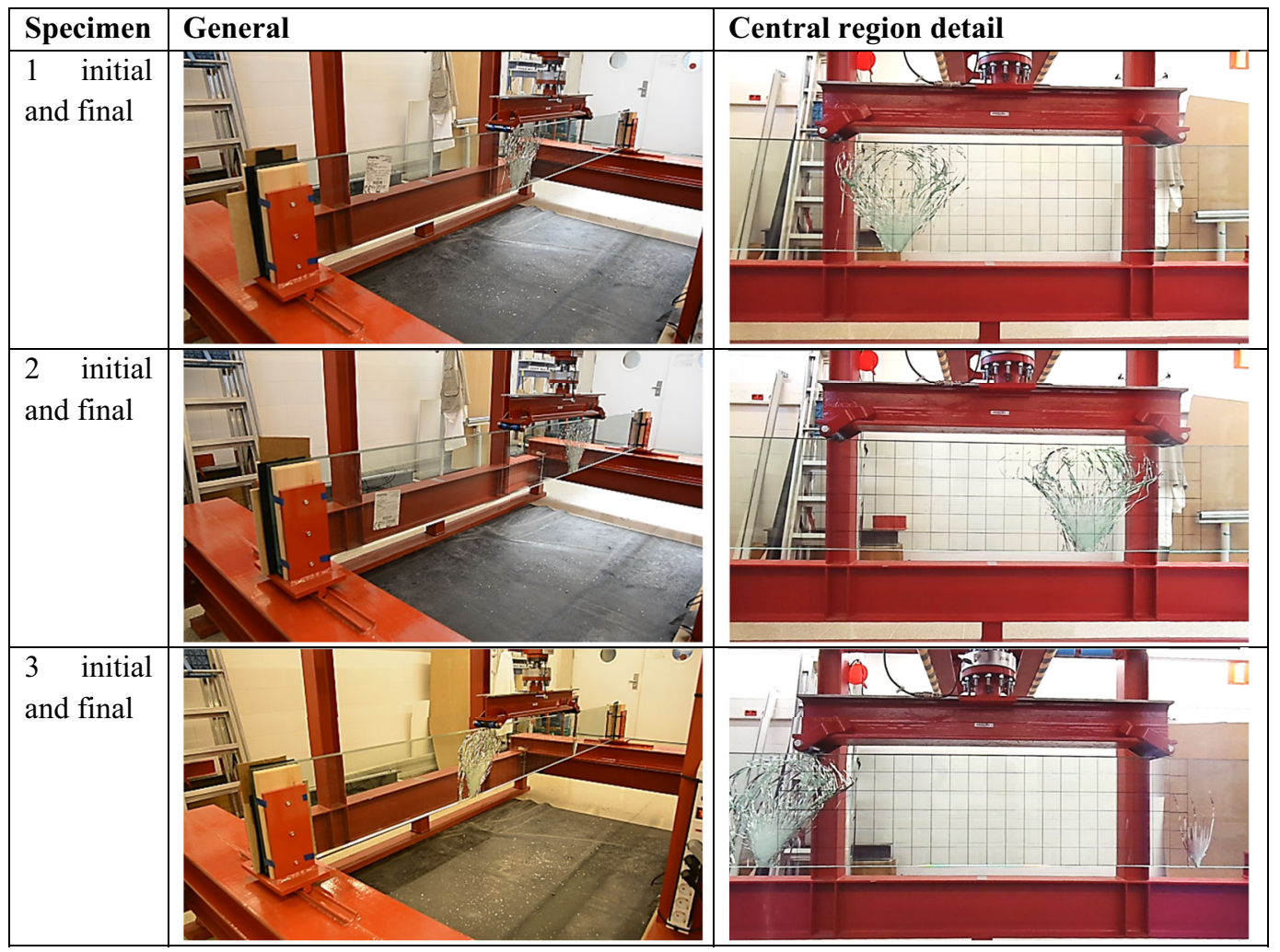

Fig. 14 Initial breakage and final collapse of specimens of the beam design 5

Table 2 Average values and confidence intervals for the studied performance indicators

\begin{tabular}{llll}
\hline Design & Bending stiffness $\left[\mathrm{N} \mathrm{mm}^{2}\right]$ & Maximum bending moment $[\mathrm{k} \mathrm{N} \mathrm{m}]$ & Redundancy $[\mathrm{k} \mathrm{N}]$ \\
\hline 1 & $1.96 \mathrm{E}+12 \pm 7.91 \mathrm{E}+10$ & $32.62 \pm 3.57$ & $0.00 \pm 0.00$ \\
2 & $1.99 \mathrm{E}+12 \pm 7.74 \mathrm{E}+10$ & $33.30 \pm 2.47$ & $0.82 \pm 0.86$ \\
3 & $1.81 \mathrm{E}+12 \pm 4.28 \mathrm{E}+10$ & $25.21 \pm 4.25$ & $1.77 \pm 1.69$ \\
4 & $1.86 \mathrm{E}+12 \pm 3.48 \mathrm{E}+10$ & $30.34 \pm 2.12$ & $3.51 \pm 2.21$ \\
5 & $1.96 \mathrm{E}+12 \pm 7.91 \mathrm{E}+10$ & $35.81 \pm 3.88$ & $0.00 \pm 0.00$ \\
\hline
\end{tabular}

According to the results shown in Fig. 6, as well as the pictures presented from Figs. 10, 11, 12, 13, 14, some specimens presented small fractures of single sheets of glass before the total collapse, other specimens experienced a simultaneous breakage of all glass sheets, without previous smaller glass factures, which led to total and unwarned collapse. These pictures also confirm that, in most cases, breakage occurred in the central region, between the two load application points, where the bending moment was highest and constant (Fig. 4). In some other specimens, breakage occurs under the load application points, and is caused by a combination of bending and shearing loads.

In unbroken rectangular beams subjected to pure bending, like the ones tested for this paper in its middle region (Fig. 4), the lower half of the beam experiences tensile stresses, while the top half experiences compression. Laminated glass beams generally start cracking in the central region of the beam, where the bending moment is highest, at the bottom edge, where the tensile stress is highest Biolzi et al. (2010), because glass fracture occurs when tensile stresses cause crack formation and growth from surface flaws Sundaram and Tippur 
(2018). If the laminated glass beam is only partially broken, meaning that there are still unbroken glass sheets, only the unbroken layers can still resist traction forces at the bottom region, while all the layers -broken and unbroken- can resist compression Louter et al. (2012). A stiff interlayer can limit crack growth Xu et al. (2016) and provide a beneficial stiffening effect in the bottom region by transferring part of the load from the unbroken layers to the broken adjacent ones (Speranzini and Agnetti 2015; Valarinho et al. 2013).

\subsection{Effect of the interlayer material}

Designs 1 and 2 are identical, except for the interlayer material, which is PVB Clear and SentryGlas, respectively. The same thing happens with designs 3 and 4 . Therefore, the effect of the interlayer can be evaluated by comparing design 1 with design 2 , and design 3 with design 4.

By comparing design 1 with 2, and 3 with 4, Fig. 8 shows how the maximum bending moment before glass fracture is not significantly affected by the stiffness of the interlayer material. In terms of bending stiffness (Fig. 7), specimens with SentryGlas have a slightly higher average value than specimens with PVB Clear (increase of $1,75 \%$ between designs 1 and 2, and an increase of $2,71 \%$ between designs 2 and 3). However, the interlayer stiffness does not affect the composite behaviour when it is subjected to in-plane bending, because there is no coupling through the interlayer. Hence, for what concerns the pre-breakage response, differences between SentryGlas and PVB Clear specimens is due to statistical dispersion.

With respect to post-breakage safety, the redundancy of specimens with SentryGlas was higher than the one of specimens with PVB Clear, increasing from $0.0 \mathrm{kN}$ (design 1) to $0.8 \pm 0.9 \mathrm{kN}$ (design 2), and from $1.8 \pm 1.7$ $\mathrm{kN}$ (design 3) to $3.5 \pm 2.2 \mathrm{kN}$ (design 4). However, none of these differences is statistically significant at a significance level of $5 \%$.

In addition to that, the interlayer material affected the crack size, geometry, and density; this can be observed by comparing Fig. 10 with Figs. 11, and Fig. 12 with Fig. 13. The cracked region in specimens with SentryGlas, after total collapse, started in a small region (of approximately $5 \mathrm{~cm}$ ) at the lower beam surface. The cracks originated at a single point in the bottom surface, which is subjected to tensile stress as a consequence of the positive bending moment, and then propagated in a 45-degree angle towards the top. On the top half of the beam, which is subjected to compression, the crack propagation stopped and the cracks gradually converged. On the other hand, the cracks of broken specimens with PVB Clear occupied a higher surface and had a less confined shape. Small cracks may behave as plastic hinges, and therefore may not lead to structural collapse in statically indeterminate structures Martens et al. (2016), whereas a fully broken laminated glass element with a soft interlayer behaves more like a wet towel, and relies mainly on the tensile strength of the interlayer Haldimann et al. (2008).

The differences in the crack size, geometry, and density may be due to the fact that the interlayer bonded to the adjacent unbroken glass layers has a crack bridge effect, decreasing the intensity of the stress concentration in the cracked region, and therefore limiting the crack growth Bos (2009). This phenomenon is especially present when the interlayer material is stiffer and is, therefore, able to transfer higher shear stresses between confronted glass surfaces.

5.3 Effect of the number and thickness of glass sheets

Designs 1 and 3 are identical, except for the number and thickness of glass sheets: design 1 has 3 sheets of 10 $\mathrm{mm}$ each, and design 3 has 5 sheets of $6 \mathrm{~mm}$ each. The same thing happens with designs 2 and 4 . Therefore, the effect of the number and thickness of glass sheets can be evaluated by comparing design 1 with design 3 , and design 2 with design 4.

With this comparison, it is possible to see how specimens with fewer, thicker glass sheets have a significantly higher bending stiffness (Fig. 7), with a difference of $8.27 \%$ between designs 1 and 3 , and a difference of $7.27 \%$ between designs 2 and 4 . This may be due to the fact that, even though both beams had the same moment of inertia of the cross section with respect to the horizontal axis, beams with three thicker glass sheets had a higher lateral and torsional stability than beams with five thinner glass sheets (Valarinho et al. 2016; Bedon et al. 2014; Belis et al. 2013; Machado-e-Costa et al. 2016). This means that beams with five glass sheets are more prone to experience lateral-torsional buckling, which may have been what caused the decrease in bending stiffness of beams with 
five glass sheets. A more in-depth buckling analysis is presented in Sect. 5.5.

Specimens with three glass sheets instead of five also have a significantly higher pre-breakage load-bearing capacity (Fig. 8), with a difference of $36.48 \%$ between designs 1 and 3, and a difference of $20.28 \%$ between designs 2 and 4 . The lower pre-breakage strength of specimens with five glass sheets may be due to the fact that more glass sheets means more glass edges, and therefore more chances of glass breakage at the edges of the sheets, where the strength is lower (Vandebroek et al. 2012; Agnetti 2013; prEN 2009). So, increasing the number of glass sheets has a detrimental effect on the pre-breakage mechanical performance.

Another possible reason why the load was lower in the laminated glass beams with five glass panes could be because one of the glass panes was more heavily loaded than the others. This happens if the glass panes are not perfectly aligned. Due to the lower thickness of the $6 \mathrm{~mm}$ glass panes compared to $10 \mathrm{~mm}$ panes, they would show fracture at a lower load level. This could also explain why the pre-breakage bending moment values in Fig. 8 were different for designs 3 and 4: SentryGlas was able to make a better interaction between the heavily loaded glass pane and the less loaded glass panes, creating a more cohesive behaviour, and hence first fracture happened at a higher load level compared to design 3 with PVB.

On the other hand, with respect to the post-breakage behaviour, specimens with five glass sheets have a more progressive breakage and a higher redundancy. This is mainly due to the fact that the interlayer had a crack stopping effect and therefore, after initial cracking, these beams had four unbroken glass sheets out of five instead of two out of three. The redundancy increases in beams with PVB Clear from $0 \mathrm{kN}$ (design 1) to $1.8 \pm 1.7 \mathrm{kN}$ (design 3), and in beams with SentryGlas from $0.8 \pm 0.9 \mathrm{kN}$ (design 2) to $3.5 \pm 2.2 \mathrm{kN}$ (design 4). This means that specimens with five glass sheets are safer than specimens with three glass sheets, because they have a higher safety margin between the first sign of structural overload or unexpected cracking and the total structural collapse.

\subsection{Effect of the thermal strengthening of glass}

Designs 2 and 5 are identical, except for the thermal strengthening of the glass sheets, which is annealed in design 2 and heat-strengthened in design 5. So, the effect of the thermal strengthening of glass sheets can be evaluated by comparing these two designs.

According to results presented in Figs. 7 and 8, using heat-strengthened glass instead of annealed glass does not significantly affect the bending stiffness and maximum pre-breakage bending moment respectively, although heat-strengthened glass is supposed to have a higher bending strength than annealed glass prEN (2009). This may be due to the fact that the in-plane response of laminated glass beams is strongly affected by the edge finishes, and not so much by the strengthening process, which mainly affects the out-of-plane response ISO (2016).

On the other hand, differences were observed in terms of post-breakage performance. All specimens with heat-strengthened glass experienced an instantaneous collapse without previous warning (Fig. 14), unlike specimens with annealed glass, which presented a small but non-negligible redundancy or load safety margin (Fig. 9).

\subsection{Buckling analysis of the laminated glass beams}

According to the results presented in Sect. 4, laminated glass specimens with more yet thinner glass layers (but same glass total thickness) exhibit a lower maximum strength. This is not expected from theory because the inertia with respect to the strong axis is the same. However, it was indicated in Sect. 5.3 that these beams are more prone to experience lateral torsional buckling, because beams with thinner layers have a higher slenderness with respect to the weak axis.

Given the viscoelastic behaviour of the interlayer material, the out-of-plane buckling is not only affected by factors such as the beam slenderness or the geometrical imperfections of the glass layers. Instead, factors such as the load duration, the material temperature and the bond between glass and interlayer may also have an influence on the out-of-plane buckling. Some authors have studied this complex behaviour through experimental testing, numerical simulation or analytical methods (Galuppi and Royer-Carfagni 2012; ISO 2016; Amadio and Bedon 2012; Galuppi and RoyerCarfagni 2014; Amadio and Bedon 2013; Belis et al. 2013; Santo et al. 2020).

In this section, a numerical study of the lateral torsional buckling critical loads is presented. These loads 
Table 3 Dimensions of the laminated glass beams with 3 (model A) and 5 (model B) glass layers

\begin{tabular}{llllll}
\hline Model & Length $[\mathrm{mm}]$ & Height $[\mathrm{mm}]$ & Width $[\mathrm{mm}]$ & $\begin{array}{l}\text { Number of glass layers } \mathrm{x} \\
\text { (thickness }[\mathrm{mm}])\end{array}$ & $\begin{array}{l}\text { Number of polymeric layers } \\
\mathrm{x}(\text { thickness }[\mathrm{mm}])\end{array}$ \\
\hline A & 3100 & 300 & 33.04 & $3 \times(10)$ & $2 \times(1.52)$ \\
B & 3100 & 300 & 36.08 & $5 \times(6)$ & $4 \times(1.52)$ \\
\hline
\end{tabular}

Table 4 Material mechanical properties used in the numerical simulations

\begin{tabular}{lll}
\hline Material & Young modulus [GPa] & Poisson ratio \\
\hline Glass & 72 & 0.22 \\
SentryGlas $(t=300 s)$ & 0.46 & 0.36 \\
PVB Clear $(t=300 s)$ & 0.26 & 0.38 \\
\hline
\end{tabular}

are then compared with the maximum loads obtained experimentally. The numerical models were assembled in ABAQUS CAE using the geometrical dimensions presented in Table 3. Model A corresponds with design numbers 1, 2 and 5 whereas model B corresponds with design numbers 2 and 3 (Table 3 ).

Linear elastic behaviour was assumed for both the glass and polymeric interlayers. As the interlayers could present viscoelastic relaxation due to lateral torsional buckling, a Young modulus corresponding to the testing time $\mathrm{t}=300 \mathrm{~s}$ and room temperature $\mathrm{T}=20^{\circ} \mathrm{C}$ was considered in the calculations. The mechanical properties of the materials used in the numerical simulations are presented in Table 4. The Young modulus of the interlayer materials were obtained in a previous work Centelles et al. (2021).

The glass layers of the finite element model were meshed with 3D linear shell continuum elements (SC8R) Abaqus (2020) whereas the PVB layers were meshed with 3D linear hexahedral elements (C3D8R). The approximate size for the elements is $25 \mathrm{~mm}(2.5-3$ times the glass layer thickness). On the other hand, one element for layer is used trough laminated glass thickness. This meshing technique has been demonstrated to be adequate to reproduce the laminated glass behaviour with a relatively low computational time (Fröling and Persson 2013; Centelles et al. 2021). A detail of the mesh for each model is presented in Fig. 15.

The boundary conditions considered in the experimental tests were replicated in the numerical models. They were applied according to the testing configura- tion presented in Fig. 3, being the average load $35 \mathrm{kN}$ for model A and $25 \mathrm{kN}$ for model B (Fig. 6).

The first lateral torsional buckling mode shapes corresponding to both models with SentryGlas interlayers are shown in Fig. 16. It can be observed that the shapes for both modes are similar but not equal. The same mode shapes were obtained for the two models with PVB Clear as interlayer material.

The lateral torsional buckling critical load for each simulated case is presented in Table 5. From the results it can be inferred that, under the simulated conditions, design number cases 1,2, and 4 would occur mainly due to bending, the lateral torsional buckling being negligible. On the other hand, the critical load for design number 3 is in the same range as the failure load (22$30 \mathrm{kN}$ ) obtained in the experiments. Therefore, in that case, the failure due to bending could be accompanied by lateral torsional buckling. This phenomenon can be observed in Fig. 6c, where the curves corresponding to design number 3 tend to a horizontal line before failure.

Moreover, it is inferred from the numerical simulations that laminated glass beams with SentryGlas present a better buckling behaviour than with PVB Clear interlayer. This is due to the different stiffness exhibited by each material, higher for SentryGlas. On the other hand, for the same total thickness of the beams, the lateral torsional buckling load increases with a decreasing number of glass layers.

\subsection{Comparison with other laminated glass beam bending tests}

Table 6 shows the results from these tests in comparison with some other similar tests found in the literature. All of the presented results correspond to four-point bending tests, showing that it is preferable to threepoint bending tests and others.

The maximum stress was calculated dividing the bending moment by the section modulus $\left(\mathrm{W}_{\mathrm{z}}\right)$, considering only the glass layers (i.e., neglecting the inter- 


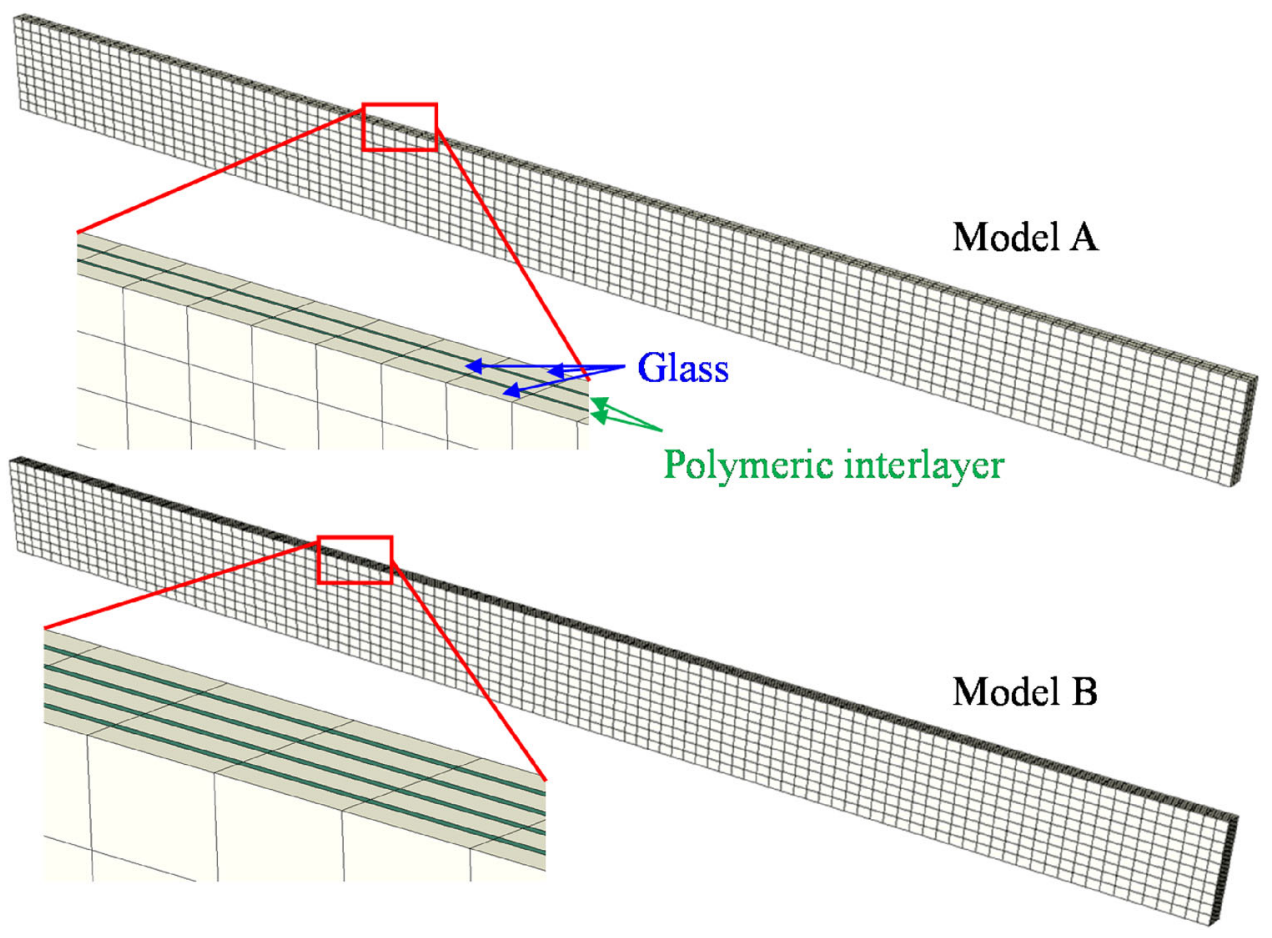

Fig. 15 Finite element models used in the buckling analysis
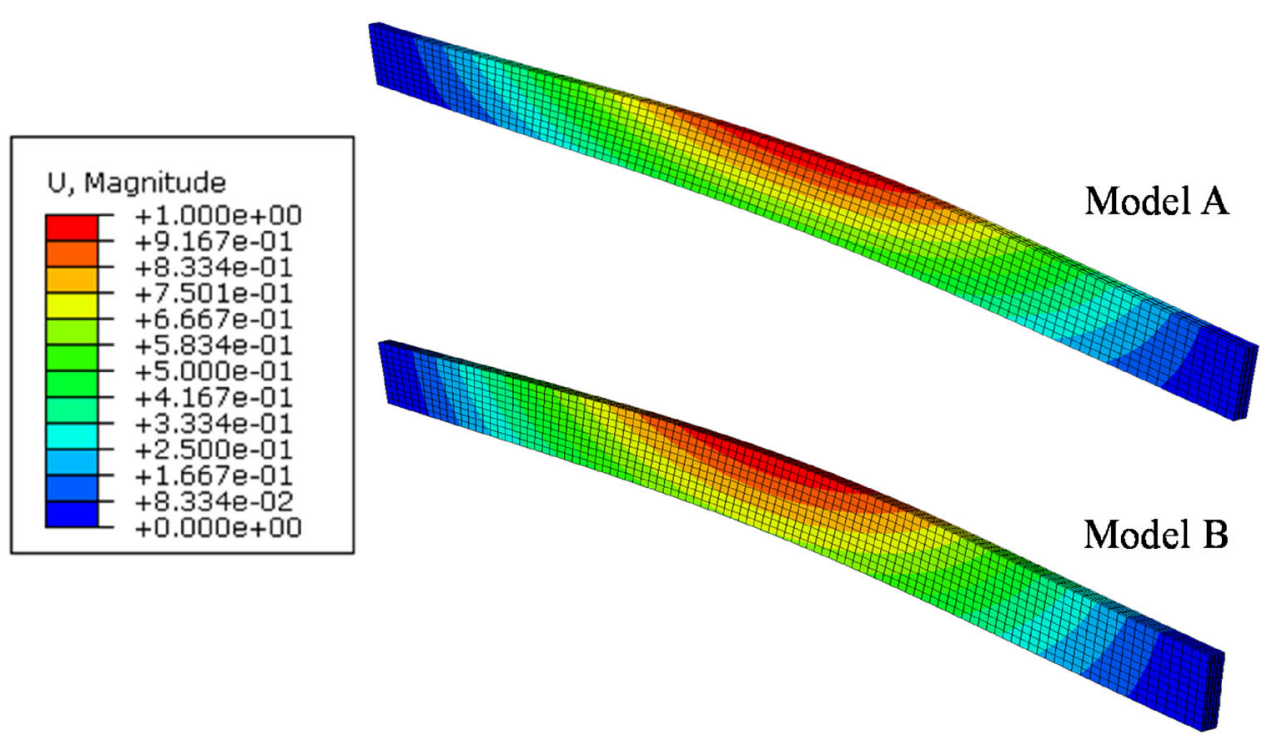

Fig. 16 First buckling mode for both models 
Table 5 Critical buckling load for the laminated glass beams

\begin{tabular}{llll}
\hline Model & Interlayer & Design & Critical buckling load \\
\hline A & SentryGlas & 2 & $182 \mathrm{kN}$ \\
A & PVB Clear & 1 & $93 \mathrm{kN}$ \\
B & SentryGlas & 4 & $70 \mathrm{kN}$ \\
B & PVB Clear & 3 & $26 \mathrm{kN}$ \\
\hline
\end{tabular}

layer). There does not seem to be a correlation between the maximum stress and the gas slype, confirming the previous statement that the in-plane response of laminated glass beams is strongly affected by the edge finishes, and not so much by the strengthening process. The moment/deflection ratio provides information about the bending stiffness, being proportional to $\mathrm{EI} / \mathrm{L}^{2}$.

Besides the differences in the cross-section area and the distance between supports, the laminated glass beams gathered from the literature had important design differences with respect to the tested ones which may have led to the differences in the results.

The beams designed and tested by Speranzini et al. Speranzini and Agnetti (2015) had a GFRP reinforcement at the bottom surface. In addition to that, they were thicker but significantly shorter, and this is probably why the maximum bending load is lower than in the beams from this paper. These beams had a higher post-breakage safety margin thanks to the contribution of the GFRP reinforcement after the initial glass breakage.

The beams from Louter et al. (2012) had a metallic reinforcement at the bottom; that is probably why these had a higher bending moment despite being thinner and shorter than the ones tested in this paper. The exact numerical values from the displacement are not presented in the paper, but according to the loaddisplacement diagrams, the initial cracking occurs at approximately $5 \mathrm{~mm}$ deflection and total collapse at approximately $40 \mathrm{~mm}$. The big margin between the initial cracking and the total collapse is due to the contribution of the steel reinforcement.

The beams from Santarsiero et al. Santarsiero et al. (2017) were split in half and had a metallic embedded connection at the midspan; that is most likely the reason why the maximum bending load was lower despite the beam having metallic reinforcements at the top and at the bottom. There were different connection designs, affecting both pre- and post-breakage structural response of the beams. The results presented in Table 6 correspond to the most resistant of the three tested connection types. These metallic connections may be the ones that have caused these beams to have a significantly lower bending stiffness than the rest of the beams: the other ones were within the $4.26 \pm 0.37$ $\mathrm{kNm} / \mathrm{mm}$ range, whereas the ones with metallic connections decreased to $2.11 \mathrm{kNm} / \mathrm{mm}$.

\section{Conclusions}

A four-point bending test was performed on laminated glass beams. Five different beam designs were tested and compared. All specimens had the same external dimensions of $3100 \times 300 \times 30 \mathrm{~mm}$, but different number and thickness of glass sheets $(3 \times 10 \mathrm{~mm}$ or $5 \times 6$ $\mathrm{mm}$ ), interlayer materials (PVB Clear or SentryGlas), and thermal treatment of glass sheets (annealed or heatstrengthened). The behaviour of each laminated glass beam design was evaluated and compared based on the pre-breakage (maximum bending moment and bending stiffness) and post-breakage (breakage mode and redundancy) key performance indicators.

The main issue with fully transparent laminated glass beams is its lack of post-breakage strength and ductility. This can be solved by adding reinforcements of more ductile materials such as steel, or by adding sacrificial glass sheets. However, it is also possible to have safer laminated glass beams by choosing the adequate number of glass sheets, type of glass, and interlayer material.

All specimens presented a linear elastic behaviour until initial glass breakage. Specimens with three glass sheets presented a higher pre-breakage maximum bending moment and bending stiffness. This could be due to the fact that these are less prone to experience lateral-torsional buckling. The buckling analysis showed that the critical buckling load was higher than the maximum load of the beams, and therefore failure was caused by glass failure due to in-plane bending, for all beam designs except the one with five glass layers and PVB Clear interlayer. In this last case the failure due to bending may be accompanied by lateral torsional buckling. However, the maximum load difference between specimens with three and five glass sheets could also be due to misalignment of the glass panes, which would cause one of the glass panes to be 


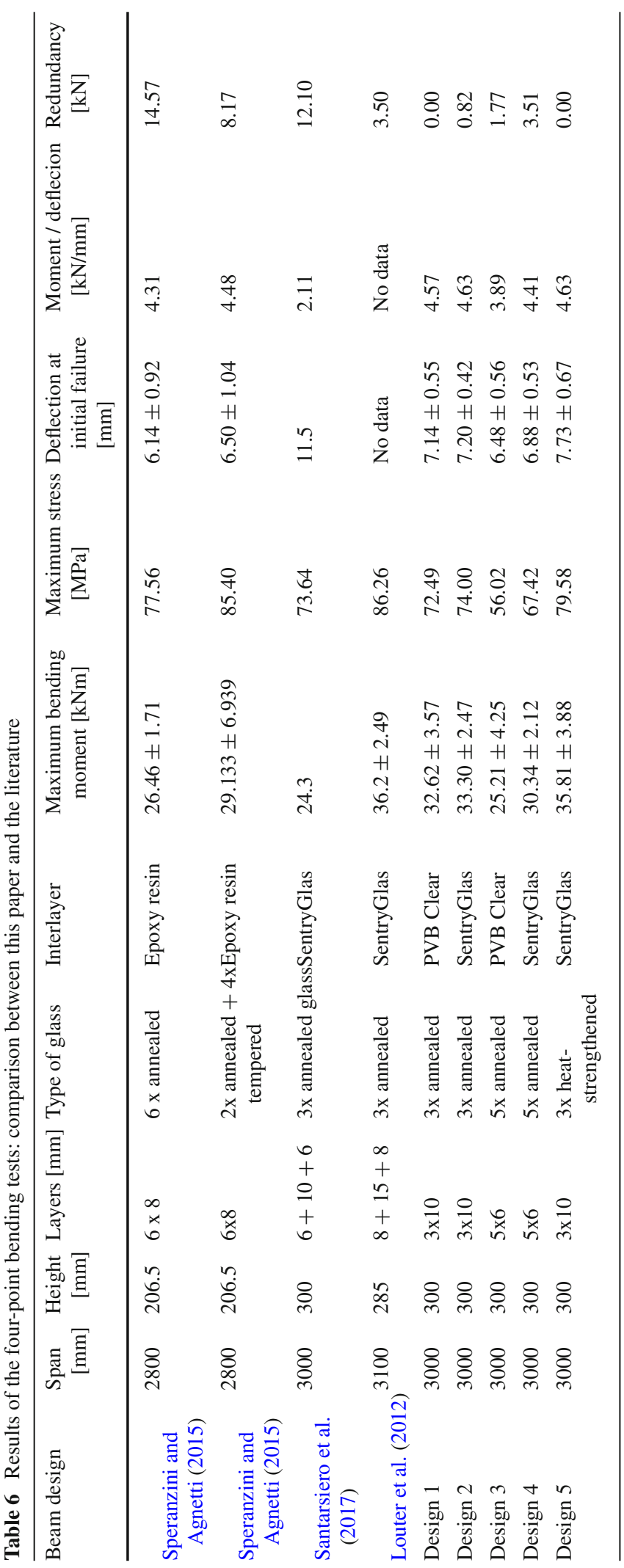


more heavily loaded than the others, and since these glass panes are thinner in beams with five glass sheets, it would lead to fracture at lower load levels.

On the other hand, specimens with five glass sheets presented a higher redundancy and a more progressive breakage. The comparisons with other experimental tests confirmed that laminated glass beams reinforced with a more ductile material had a higher redundancy and therefore a more gradual collapse. However, the laminated glass beams with more glass layers and a stiffer interlayer tested in this paper had a small yet important post-breakage safety margin.

Using heat-strengthened glass instead of annealed glass had a detrimental effect on the post-breakage safety, and a negligible effect on the pre-breakage performance, probably because the in-plane response of laminated glass beams is strongly affected by the edge finishes. Specimens with SentryGlas instead of PVB Clear had a higher redundancy, and the cracks after total collapse were confined in a smaller region.

Acknowledgements The work was partially funded by CRISTEC with CDTI funds (IDI-20160588). The authors at the University of Lleida would like to thank the Catalan Government for the quality accreditation given to their research group GREiA (2017 SGR 1537). GREiA is certified agent TECNIO in the category of technology developers from the Government of Catalonia. This work is partially supported by ICREA under the ICREA Academia programme. The financing support given by the Spanish Ministry of Economy and Competitiveness through the project BIA2014-53774-R is gratefully appreciated. Xavier Centelles would like to thank University of Lleida for his research fellowship and to the University of Oviedo for hosting his secondment during 2019.

Funding Open Access funding provided thanks to the CRUECSIC agreement with Springer Nature.

Data Availability Statement The raw data required to reproduce these findings are available upon request.

Open Access This article is licensed under a Creative Commons Attribution 4.0 International License, which permits use, sharing, adaptation, distribution and reproduction in any medium or format, as long as you give appropriate credit to the original author(s) and the source, provide a link to the Creative Commons licence, and indicate if changes were made. The images or other third party material in this article are included in the article's Creative Commons licence, unless indicated otherwise in a credit line to the material. If material is not included in the article's Creative Commons licence and your intended use is not permitted by statutory regulation or exceeds the permitted use, you will need to obtain permission directly from the copyright holder. To view a copy of this licence, visit http://creativecommons.org/licenses/ by/4.0/.

\section{References}

Abaqus User's Manual, Dassault Systémes Simulia Corp., Providence, Rhode Island, USA (2020)

Agnetti, S.: Strength on cut edge and ground edge glass beams with the failure analysis method. Fract. Struct. Integr. 7, 480-489 (2013). https://doi.org/10.3221/IGF-ESIS.26.04

Amadio, C., Bedon, C.: Analytical approaches for buckling verification of in-plane loaded laminated glass columns and panels. In: Conference: Challenging Glass 3-Conference on Architectural and Structural Applications of Glass, pp. 373386 (2012)

Amadio, C., Bedon, C.: A buckling verification approach for monolithic and laminated glass elements under combined in-plane compression and bending. Eng. Struct. 52, 220-229 (2013). https://doi.org/10.1016/j.engstruct.2013. 02.022

Andreozzi, L., Bati, S.B., Fagone, M., Ranocchiai, G., Zulli, F.: Dynamic torsion tests to characterize the thermoviscoelastic properties of polymeric interlayers for laminated glass. Constr. Build. Mater. 65, 1-13 (2014). https:// doi.org/10.1016/J.CONBUILDMAT.2014.04.003

Bedon, C., Louter, C.: Finite Element analysis of post-tensioned SG-laminated glass beams with adhesively bonded steel tendons. Compos. Struct. 167, 238-250 (2017). https://doi.org/ 10.1016/j.compstruct.2017.01.086

Bedon, C., Santarsiero, M.: Laminated glass beams with thick embedded connections-numerical analysis of fullscale specimens during cracking regime. Compos. Struct. 195, 308-324 (2018). https://doi.org/10.1016/j.compstruct. 2018.04.083

Bedon, C., Belis, J., Luible, A.: Assessment of existing analytical models for the lateral torsional buckling analysis of PVB and SG laminated glass beams via viscoelastic simulations and experiments. Eng. Struct. 60, 52-67 (2014). https://doi. org/10.1016/j.engstruct.2013.12.012

Belis, J., Depauw, J., Callewaert, D., Delincé, D., Van Impe, R.: Failure mechanisms and residual capacity of annealed glass/SGP laminated beams at room temperature. Eng. Fail. Anal. 16, 1866-1875 (2009). https://doi.org/10.1016/ j.engfailanal.2008.09.023

Belis, J., Bedon, C., Louter, C., Amadio, C., Van Impe, R.: Experimental and analytical assessment of lateral torsional buckling of laminated glass beams. Eng. Struct. 51, 295-305 (2013). https://doi.org/10.1016/j.engstruct.2013.02.002

Belis, J., Bedon, C., Louter, C., Amadio, C., Van Impe, R.: Experimental and analytical assessment of lateral buckling of laminated glass beams. Eng. Struct. 51, 295-305 (2013). https:// doi.org/10.1016/j.engstruct.2013.02.002

Biolzi, L., Cattaneo, S., Rosati, G.: Progressive damage and fracture of laminated glass beams. Constr. Build. Mater. 24, 577-584 (2010). https://doi.org/10.1016/j.conbuildmat. 2009.09.007

Biolzi, L., Cattaneo, S., Orlando, M., Piscitelli, L.R., Spinelli, P.: Post-failure behavior of laminated glass beams using different interlayers. Compos. Struct. 202, 578-589 (2018). https://doi.org/10.1016/j.compstruct.2018.03.009

Bokel, R.M.J., Veer, F.A., Tuisinga, L.: Fire resistance of glass. In: Proceedings of Glass Processing Days, pp. 362-363 (2003) 
Bonati, A., Pisano, G., Royer-Carfagni, G.: Redundancy and robustness of brittle laminated plates. Overlooked aspects in structural glass. Compos. Struct. 227, 111288 (2019). https://doi.org/10.1016/j.compstruct.2019.111288

Bos, F.P.: Safety Concepts in Structural Glass Engineering: Towards an Integrated Approach. PhD dissertation, TU Delft, ISBN 987-90-8570-428-7 (2009)

Bridgestone (2016). The glass experience-Films de inserción

Calderone, I., Davies, P.S., Bennison, S.J., Huang, X., Gang, L.: Effective laminate thickness for the design of laminated glass. Glass performance days (Tampere, 2009), Glaston Finland/GPD, Tampere (2009)

CEN/TC 250. prCEN/TS xxxx-1: 2019-In-Plane Loaded Glass Components (December 2019); CEN-European Committee for Standardization: Brussels, Belgium (2019)

CEN-TC250WG3. prEN 16612: glass in building-determination of the load resistance of glass panes by calculation and testing. Project of European Stardard (2013)

Centelles, X., Castro, J.R., Cabeza, L.F.: Experimental results of mechanical, adhesive, and laminated connections for laminated glass elements-a review. Eng. Struct. 180, 192-204 (2019). https://doi.org/10.1016/j.engstruct.2018.11.029

Centelles, X., Martín, M., Solé, A., Castro, J.R., Cabeza, L.F.: Tensile test on interlayer materials for laminated glass under diverse ageing conditions and strain rates. Constr. Build. Mater. 243, 118230 (2020). https://doi.org/10.1016/ j.conbuildmat.2020.118230

Centelles, X., Pelayo, F., Lamela-Rey, M.J., Fernández, A.I., Salgado-Pizarro, R., Castro, J.R., Cabeza, L.F.: Viscoelastic characterization of seven laminated glass interlayer materials from static tests. Constr. Build. Mater. 279, 122503 (2021). https://doi.org/10.1016/j.conbuildmat. 2021.122503

Centelles, X., Pelayo, F., Aenlle-López, M., Castro, J.R., Cabeza, L.F.: Long-term loading and recovery of a laminated glass slab with three different interlayers. Constr. Build. Mater. 287, 122991 (2021). https://doi.org/10.1016/j.conbuildmat. 2021.122991

Chen, X., Chan, A.H.C., Yang, J.: Simulating the breakage of glass under hard body impact using the combined finite-discrete element method. Comput. Struct. 177, 56-68 (2016). https://doi.org/10.1016/j.compstruc.2016.08.010

Chen, S., Zang, M., Wang, D., Yoshimura, S.: Tomonori Yamada. Numerical analysis of impact failure of automotive laminated glass: a review. Composites Part B 122, 47-60 (2017). https://doi.org/10.1016/j.compositesb.2017.04.007

Feldmann, M., Kasper, R. et al.: Guidance for European structural design of glass components support to the implementation, harmonization and further development of the Eurocodes. Report EUR 26439 EN. Publications Office of the European Union, Luxembourgh (2014) ISBN 978-92-79-350931 (pdf). https://doi.org/10.2788/5523

Fröling, M., Persson, K.: Computational Methods for Laminated Glass. J. Eng. Mech. 139, 780-790 (2013). https://doi.org/ 10.1061/(ASCE)EM.1943-7889.0000527

Galuppi, L., Royer-Carfagni, G.: Effective thickness of laminated glass beams: new expression via a variational approach. Eng. Struct. 38, 53-67 (2012). https://doi.org/10.1016/j. engstruct.2011.12.039

Galuppi, L., Royer-Carfagni, G.: Buckling of three-layered composite beams with viscoelastic interaction. Compos. Struct.
107, 512-521 (2014). https://doi.org/10.1016/j.compstruct. 2013.08.006

Galuppi, L., Royer-Carfagni, G.: The post-breakage response of laminated heat-treated glass under in plane and out of plane loading. Compos. B 147, 227-239 (2018). https://doi.org/ 10.1016/j.compositesb.2018.04.005

Galuppi, L., Royer-Carfagni, G.: Enhanced Effective Thickness for laminated glass beams and plates under torsion. Eng. Struct. 206, 110077 (2020). https://doi.org/10.1016/j. engstruct.2019.110077

Galuppi, L., Manara, G., Royer Carfagni, G.: Practical expressions for the design of laminated glass. Compos. B Eng. 45, 1677-1688 (2013). https://doi.org/10.1016/j.compositesb. 2012.09.073

Gao, W., Wang, R., Chen, S., Zang, M.: An intrinsic cohesive zone approach for impact failure of windshield laminated glass subjected to a pedestrian headform. Int. J. Impact Eng. 126, 147-159 (2019). https://doi.org/10.1016/j.ijimpeng. 2018.12.013

Griffith, A.A.: The phenomena of rupture and flow in solids. Philos. Trans. R. Soc. Lond. 221, 163-198 (1921). https:// doi.org/10.1098/rsta.1921.0006

Haldimann, M., Luible, A., Overend, M.: Structural use of glass. IABSE-AIPC-IVBH, Zürich, 978-3-85748-119-2 (2008)

ISO 1288-3: 2016-Glass in building-determination of the bending strength of glass-part 3: test with specimen supported at two points (four point bending)

Jentsch, A., Eichhorn, K.-J., Voit, B.: Influence of typical stabilizers on the aging behavior of EVA foils for photovoltaic applications during artificial UV-weathering. Polym. Testing 44, 242-247 (2015). https://doi.org/10. 1016/j.polymertesting.2015.03.022

Karlsson, S., Jonson, B., Stålhandske, C.: The Technology of Chemical Glass Strengthening - A Review. Glass Technology: European Journal of Glass Science and Technology Part A 2, pp. 41-54. ISSN 1753-3554 (2010)

Kozłowski, M.: Experimental and numerical assessment of structural behaviour of glass balustrade subjected to soft body impact. Compos. Struct. 229, 111380 (2019). https://doi. org/10.1016/j.compstruct.2019.111380

Lindqvist, M., Louter, C.: Experimental study on glass edge machining flaw Characterization. Eng. Fract. Mech. 127, 56-70 (2014). https://doi.org/10.1016/j.engfracmech.2014. 05.008

Liu, B., Xu, T., Xu, X., Wang, Y., Sun, Y., Li, Y.: Energy absorption mechanism of polyvinyl butyral laminated windshield subjected to head impact: experiment and numerical simulations. Int. J. Impact Eng. 90, 26-36 (2016). https://doi. org/10.1016/j.ijimpeng.2015.11.010

López-Aenlle, M., Noriega, A., Pelayo, F.: Mechanical characterization of polyvinil butyral from static and modal tests on laminated glass beams. Compos. B 169, 9-18 (2019). https://doi.org/10.1016/j.compositesb.2019.03.077

Louter, C., Nussbaumer, A.: Fire testing of structural glass beams: initial experimental results. In: 2016 GlassCon Global Proceedings Book. ISBN 978-0-9975156-0-2, pp. 143-150 (2016)

Louter, C., Belis, J., Veer, F., Lebet, J.-P.: Structural response of SG-laminated reinforced glass beams; experimental investigations on the effects of glass type, reinforcement percent- 
age and beam size. Eng. Struct. 36, 292-301 (2012). https:// doi.org/10.1016/j.engstruct.2011.12.016

Louter, C., Belis, J., Veer, F., Lebet, J.-P.: Durability of SGlaminated reinforced glass beams: effects of temperature, thermal cycling, humidity and load-duration. Constr. Build. Mater. 27, 280-292 (2012). https://doi.org/10.1016/ j.conbuildmat.2011.07.046

Lyu, Y., Kim, J.H., Gu, X.: Developing methodology for service life prediction of PV materials: quantitative effects of light intensity and wavelength on discoloration of a glass/EVA/PPE laminate. Sol. Energy 174, 515-526 (2018). https://doi.org/10.1016/j.solener.2018.08.067

Machado-e-Costa, M., Valarinho, L., Silvestre, N., Correia, J.R.: Modeling of the structural behavior of multilayer laminated glass beams: Flexural and torsional stiffness and lateral-torsional buckling. Eng. Struct. 128, 265-282 (2016). https://doi.org/10.1016/j.engstruct.2016.09.014

Martens, K., Caspeele, R., Belis, J.: Development of composite glass beams-a review. Eng. Struct. 101, 1-15 (2015). https:// doi.org/10.1016/j.engstruct.2015.07.006

Martens, K., Caspeele, R., Belis, J.: Development of Reinforced and Posttensioned Glass Beams: Review of Experimental Research. J. Struct. Eng. 142, 112 (2016). https://doi.org/ 10.1061/(ASCE)ST.1943-541X.0001453

Martens, K., Caspeele, R., Belis, J.: Experimental investigations of statically indeterminate reinforced glass beams. Constr. Build. Mater. 119, 296-307 (2016). https://doi.org/10. 1016/j.conbuildmat.2016.04.151

Martín, M., Centelles, X., Solé, A., Barreneche, C., Fernández, A.I., Cabeza, L.F.: Polymeric interlayer materials for laminated glass: a review. Constr. Build. Mater. 230, 116897 (2020). https://doi.org/10.1016/j.conbuildmat. 2019.116897

Pelayo, F., López-Aenlle, M., Ismael, G., Fernández-Canteli, A.: Buckling of multilayered laminated glass beams: validation of the effective thickness concept. Compos. Struct. 169, 2-9 (2017). https://doi.org/10.1016/j.compstruct.2017.01.040

Pelayo, F., Lamela-Rey, M.J., Muniz-Calvente, M., LópezAenlle, M., Álvarez-Vázquez, A., Fernández-Canteli, A.: Study of the time-temperature-dependent behaviour of PVB: application to laminated glass elements. Thin-Walled Struct. 119, 324-31 (2017). https://doi.org/10.1016/J.TWS. 2017.06.030

prEN 13474-3: 2009-Glass in building-determination of the strength of glass panes-part 3: general method of calculation and determination of strength of glass by testing

Rivers, G., Cronin, D.: Influence of moisture and thermal cycling on delamination flaws in transparent armor materials: Thermoplastic polyurethane bonded glass-polycarbonate laminates. Materials \& Design 182, 108026 (2019). https://doi. org/10.1016/j.matdes.2019.108026

Ronchetti, C., Lindqvist, M., Louter, C., Salerno, G.: Stresscorrosion failure mechanisms in soda-lime silica glass. Eng. Fail. Anal. 35, 427-438 (2013). https://doi.org/10.1016/j. engfailanal.2013.03.028

Rühl, A., Kolling, S., Schneider, J.: A transparent three-layered laminate composed of poly(methyl methacrylate) and thermoplastic polyurethane subjected to low-velocity impact. Int. J. Impact Eng 136, 103419 (2020). https://doi.org/10. 1016/j.ijimpeng.2019.103419
Santarsiero, M., Louter, C., Nussbaumer, A.: Laminated connections for structural glass applications under shear loading at different temperatures and strain rates. Constr. Build. Mater. 128, 214-237 (2016). https://doi.org/10. 1016/j.conbuildmat.2016.10.045

Santarsiero, M., Louter, C., Nussbaumer, A.: Laminated connections under tensile load at different temperatures and strain rates. Int. J. Adhes. Adhes. 79, 23-49 (2017). https://doi. org/10.1016/j.ijadhadh.2017.09.002

Santarsiero, M., Louter, C., Nussbaumer, A.: Laminated connections for structural glass components: a full-scale experimental study. Glass Struct. Eng. 2, 11-79 (2017). https:// doi.org/10.1007/s40940-016-0033-2

Santarsiero, M., Bedon, C., Louter, C.: Experimental and numerical analysis of thick embedded laminated glass connections. Compos. Struct. 188, 242-256 (2018). https://doi.org/10. 1016/j.compstruct.2018.01.002

Santo, D., Mattei, S., Bedon, C.: Elastic critical moment for the lateral-torsional buckling (LTB). Analysis of structural glass beams with discrete mechanical lateral restraints. Materials 13, 2492 (2020). https://doi.org/10. 3390/ma13112492

Serafinavičius, T., Lebet, J.-P., Louter, C., Lenkimas, T., Kuranovas, A.: Long-term laminated glass four point bending test with PVB, EVA and SG interlayers at different temperatures. Procedia Eng. 57, 996-1004 (2013). https://doi.org/ 10.1016/j.proeng.2013.04.126

Sjöström, J., Kozłowski, M., Honfi, D., Lange, D., Albrektsson, J., Lenk, P., Eriksson, J.: Fire resistance testing of a timberglass composite beam. Int. J. Struct. Glass Adv. Mater. Res

Speranzini, E., Agnetti, S.: Flexural performance of hybrid beams made of glass and pultruded GFRP. Constr. Build. Mater. 94, 249-262 (2015). https://doi.org/10.1016/j.conbuildmat. 2015.06.008

Sundaram, B.M., Tippur, H.V.: Dynamic fracture of soda-lime glass: a full-field optical investigation of crack initiation, propagation and branching. J. Mech. Phys. Solids 11, 13253 (2018). https://doi.org/10.1016/J.JMPS.2018.04.010

To, Q.D., He, Q.-C., Cossavella, M., Morcant, K., Panait, A., Yvonnet, J.: The tempering of glass and the failure of tempered glass plates with pin-loaded joints: modelling and simulation. Mater. Des. 29, 943-951 (2008). https://doi.org/ 10.1016/j.matdes.2007.03.022

Valarinho, L., Correia, J.R., Branco, F.A.: Experimental study on the flexural behaviour of multi-span transparent glassGFRP composite beams. Constr. Build. Mater. 49, 10411053 (2013). https://doi.org/10.1016/j.conbuildmat.2012. 11.024

Valarinho, L., Correia, J.R., Machado-e-Costa, M., Branco, F.A., Silvestre, N.: Lateral-torsional buckling behaviour of longspan laminated glass beams: analytical, experimental and numerical study. Mater. Des. 102, 264-275 (2016). https:// doi.org/10.1016/j.matdes.2016.04.016

Vandebroek, M., Belis, J., Louter, C., Van Tendeloo, G.: Experimental validation of edge strength model for glass with polished and cut edge finishing. Eng. Fract. Mech. 96, 480489 (2012). https://doi.org/10.1016/j.engfracmech.2012. 08.019

Veer, F.A., van der Voorden, M., Rijgersberg, H., Zuidema, J.: Using transparent intumescent coatings to increase the fire resistance of glass and glass laminates. In: Proceedings of 
Glass Processing Days. ISBN 952-91-3526-2, pp. 392-396 (2013)

Wang, F.S., Yue, Z.F.: Numerical simulation of damage and failure in aircraft windshield structure against bird strike. Mater. Des. 31, 687-695 (2010). https://doi.org/10.1016/j.matdes. 2009.08.029

Weller, P.B., Weimar, D.T., Härth, D.K.: Hybrid Components of Glass and Polycarbonate, Tampere, Glass performance days, pp. 144-148. (2009)

Xu, J., Li, Y., Liu, B., Zhu, M., Ge, D.: Experimental study on mechanical behavior of PVB laminated glass under quasi-static and dynamic loadings. Compos. B 42, 302-308 (2011). https://doi.org/10.1016/j.compositesb.2010.10.009
$\mathrm{Xu}, \mathrm{X}$. , Liu, B., Li, Y.: Investigation on dynamic propagation characteristics of in-plane cracks in pvb laminated glass plates. Brittle Quasi-Brittle Fract. Eng. Mater. 56, 1468390 (2016). https://doi.org/10.1155/2016/1468390

Publisher's Note Springer Nature remains neutral with regard to jurisdictional claims in published maps and institutional affiliations. 